
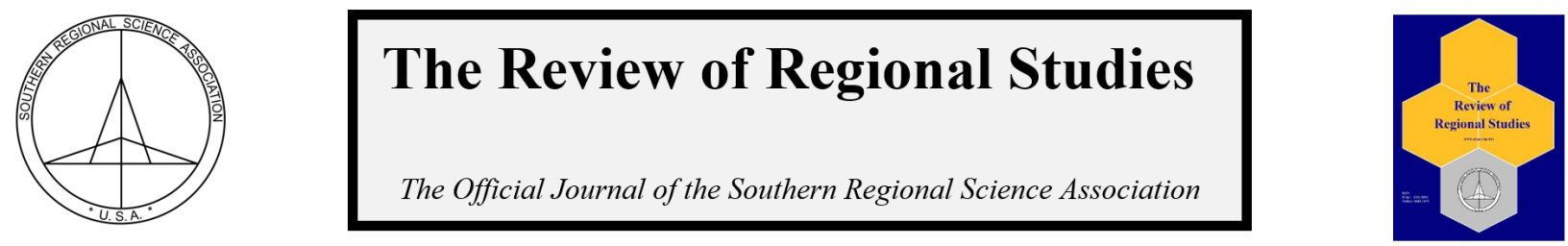

\title{
A Multi-Regional Input-Output (MRIO) Analytical Framework for Assessing the Regional Economic Impacts of Rising Water Prices*
}

\author{
Kevin Credit, ${ }^{a}$ Elizabeth Mack, ${ }^{\mathrm{b}}$ and Sarah Wrase ${ }^{\mathrm{c}}$ \\ a Committee on Geographical Sciences, University of Chicago USA \\ ${ }^{b}$ Department of Geography, Environment, and Spatial Sciences, Michigan State University, USA \\ ${ }^{c}$ Department of Accounting $\mathscr{G}$ Information Systems, Michigan State University, USA
}

\begin{abstract}
Understanding the regional economic implications of rising water and wastewater services is important, because these services are household necessities. To date, however, there are few (if any) studies examining the link between water costs and indicators of economic vitality such as jobs, output, and regional income. To advance work on this particular topic, this paper proposes a novel methodology that estimates changes in household spending information from the Consumer Expenditure Survey (CES) for a particular change in water prices. This vector of final demand changes is then linked to multi-regional input-output (MRIO) models to estimate the regional economic impacts associated with changes in consumer spending patterns. To demonstrate this methodology, three water price increase scenarios are derived, and associated changes in final demand estimated.

Keywords: water prices, multi-regional input-output analysis, Phoenix, AZ, infrastructure economic impact analysis
\end{abstract}

JEL Codes: Q25, D57, R2, R11

\section{INTRODUCTION}

The cumulative infrastructure grade for the United States is a D+ ${ }^{1}$ (American Society for Civil Engineers, 2017b). The country's drinking water and wastewater systems received

${ }^{*}$ Kevin Credit is a Lecturer in GIScience and the Assistant Director for Urban Informatics at the Center for Spatial Data Science at the University of Chicago. Elizabeth Mack is an Associate Professor in the Department of Geography, Environment, and Spatial Sciences at Michigan State University. Sarah Wrase is a Research Assistant in the Department of Accouting \& Information Systems at Michigan State University. Corresponding Author: Kevin Credit, e-mail: kcredit@uchicago.edu

${ }^{1}$ Infrastructure can receive a grade A-F: A is exceptional, B is good, $\mathrm{C}$ is mediocre, D is poor, and $\mathrm{F}$ is failing. 
grades of D and D+ respectively (American Society for Civil Engineers, 2017b). Aging drinking water infrastructure and growing demand for wastewater pose financing challenges for the utility industry since the required investments necessary to maintain and upgrade systems have been estimated to exceed $\$ 1$ trillion (American Water Works Association, 2012). As infrastructure reaches the end of its useful life - and it is increasingly infeasible for utilities to defer the costs of maintenance and upgrades - it becomes more likely that bills for drinking water and wastewater services will rise (Forer and Staub, 2013).

Recent rate analyses for the 30 largest utilities in the U.S. find a median increase of 3 percent in water rates for four person families using 50 gallons per person per day (Walton, 2017). Prior research of similar data for four person families using 100 gallons per person per day finds that rates have increased by an average of 41 percent between 2010 and 2015 with an annual average increase of 6 percent between 2014 and 2015 (Walton, 2015). However, the extent or rate increase does depend on geography (U.S. Department of Energy, 2017). In Atlanta, water rates increased 12 percent between 2010 and 2011 and between 2011 and 2012 (Walton, 2017). More recently, in Bakersfield, California, the city council approved a rate increase of 41 percent over the next two years (Mills-Gregg, 2017).

The cost of water and wastewater services is important, because these services are household necessities. Unaffordable services can lead to water shutoffs, which is an ongoing issue in Detroit, Michigan (Chapman, 2014; Hunter, 2016; Terry, 2018). A less extreme, though still important, effect of rising water costs are the impacts that higher water costs can have on household spending. Reductions in household spending on budget items to compensate for higher water rates could have regional economic implications in terms of jobs, regional income, and output.

While the impact of consumer spending in response to recessions has received research attention (Frank et al., 2010; Kamakura and Yuxing Du, 2011), there does not appear to be related literature on fluctuations in consumer spending with respect to changing water prices. Recent work, focused on China, utilized computable general equilibrium (CGE) models to analyze how water prices impact water conservation and economic growth (Zhao et al., 2016). However, there do not appear to be any studies related to water prices, changes in household spending patterns, and economic impacts at the regional level. While this is likely due to a dearth of publicly available sources about the prices that households pay for water services, in the U.S., the Consumer Expenditure Survey (CES) provides some information about the distribution of household spending, which can be used to estimate potential impacts of rising prices and associated changes in household spending.

These data, paired with input-output tables, can provide a basis for scenario assessments of the regional economic impacts of rising water prices. ${ }^{2}$ To advance work on this particular topic, this paper proposes a novel methodology that estimates changes in household spending from information in the CES for a particular change in water prices. This vector of final demand changes is then linked to multi-regional input-output (MRIO) models to estimate the regional economic impacts. To demonstrate this methodology, three water price increase scenarios are used and associated changes in final demand are estimated.

\footnotetext{
${ }^{2}$ The analysis used in this paper assumes that decreases in spending due to rising water prices are completely exogenous shocks to a regional economy. While this is certainly a simplification, it allows us to create an estimate of the relative magnitude of regional economic impacts due to rising water prices.
}

(c) Southern Regional Science Association 2019. 


\section{INFRASTRUCTURE COSTS AND WATER PRICES}

Since the 1990's, experts have acknowledged that the time has come to make large-scale replacements to the nation's water and wastewater systems (American Water Works Association, 2012). This "era of infrastructure replacement" (American Water Works Association, 2012) is necessary because of the age of systems whose useful lives are between 75 and 100 years (American Society for Civil Engineers, 2017a). Nationally, infrastructure investments took place in three time periods: the 1800's, 1900-1945, and the post-World War II era (Baird, 2010). Experts estimate that the price tag of efforts to replace, upgrade, and build new drinking water infrastructure until 2050 will exceed $\$ 1.7$ trillion dollars (American Water Works Association, 2012). Over the next 25 years, the EPA estimates that $\$ 271$ billion dollars are needed for wastewater infrastructure investments for secondary and advanced treatment, repair and construction of waste conveyance systems, the prevention of combined sewer overflows, and improved storm water management programs (Environmental Protection Agency, 2016). One of the drivers of future wastewater needs is the expansion of systems to accommodate users. For example, when rural residents switch from septic to public sewers or populations expand, new investments are required to service these customers (American Society for Civil Engineers, 2017c).

In addition to the age of infrastructure, several other factors are contributing to the rising costs of water and wastewater systems. Keeping up to date with evolving regulatory requirements to improve drinking water standards is one factor behind rising costs. This source of costs is related to the need for meeting evolving treatment standards to maintain the quality of drinking water (Copeland and Tiemann, 2010). Climate change is another factor behind rising costs that impact water and wastewater systems in a variety of ways. One impact of climate change is rising sea levels, which causes salt water to infiltrate water treatment systems and leads to increased maintenance costs (Bovarnick et al., 2014). Climate change is also linked to more intense rainfall, which can produce combined sewer and sanitary sewer overflows (Bovarnick et al., 2014).

Population trends are another big factor behind infrastructure costs and water prices. However, the link between population trends and infrastructure costs is geographically variable. In the West and South, population growth is the primary driver of infrastructure costs, while in the Midwest and Northeast, population decline means there are fewer people to pay for the growing costs of infrastructure (American Water Works Association, 2012; Faust et al., 2016). This issue has proven particularly serious for residents of Detroit, where an inability to afford the rising costs of water has led to an ongoing battle against shutoffs (Chapman, 2014; Hunter, 2016; Terry, 2018). For example, water shutoffs initiated in 2014 resulted in elimination of service for 50,000 households (Hunter, 2016). Philadelphia has also experienced water affordability problems and initiated income-based billing via a tiered-assistance program (TAP) in July of 2017 which links payments for service to income rather than water usage (Nadolny, 2017).

(c)Southern Regional Science Association 2019. 


\section{1. $\quad$ Financing Infrastructure Needs}

The issue of rising costs raises the question of how to finance infrastructure needs. Unfortunately, one of the principal means of recovering these costs is from ratepayers (American Society for Civil Engineers, 2017a). This is particularly true for public utilities who must price the services at cost (Food and Water Watch, 2016). Full cost pricing is designed to bring in enough revenue to recover the costs incurred by the utility for providing service. Examples of these costs include day-to-day operations and maintenance (treatment, distribution, and administration), as well as capital expenditures on infrastructure expansion and replacement (U.S. Environmental Protection Agency, 2006). Due to a lack of federal funding, roughly 95 percent of these costs must be funded at the local level, with the bulk of the costs falling to ratepayers in the form of rates and charges (U.S. Conference of Mayors, 2015). Rate increases are unpopular with consumers, so many utilities have deferred investments in infrastructure to maintain low rates to combat negative consumer sentiment (Beecher and Shanaghan, 1998). This continued deferral of investments, however, can increase the amount of investments needed to maintain and upgrade infrastructure (Baird, 2010).

Aside from funds received from ratepayers, debt financing is another option for some utilities. There are limits to this option for shrinking cities. Poor credit ratings and high interest on loans can render this option financially unfeasible (Fetterman, 2016). One means of reducing the burden on utilities, and subsequently on consumers, is some type of subsidy for services. Unfortunately, federal funds are increasingly unavailable for infrastructure improvements because of a combination of factors, including deficit reduction efforts and the allocation of funds to other line items (i.e. defense and homeland security) (Copeland and Tiemann, 2010). Presently, state and local governments, rather than the federal government, bear the brunt of funding water utilities. Figure 1 contains inflation-adjusted figures (billions of 2014 dollars) for spending by federal and state and local governments on highway infrastructure and water utilities between 1956 and 2014 (Congressional Budget Office, 2015). In this figure, the utilities number includes spending on both water supply and wastewater infrastructure (Congressional Budget Office, 2015). The top two lines indicate state and local spending on highways and water utilities. Compared to highway spending, water utility outlays have increased steadily since 1956, reaching a peak in 2009. Federal spending on water utilities has remained largely flat, save an uptick in spending between 1974 and 1984 .

There are other options available to water entities to fill the gap between infrastructure needs and funding availability. These options include the Drinking Water State Revolving Fund to improve drinking water quality and fund infrastructure projects (Environmental Protection Agency, 2018a) and the Clean Water State Revolving Fund (CWSRF) administered by the EPA to help finance projects for water quality (Environmental Protection Agency, 2018b). In 2014, the Water Infrastructure Finance and Innovation Act (WIFIA) passed, which is a federal program, administered by the EPA, for providing credit to a variety of entities on lower cost, and more flexible terms than might be possible with municipal or other types of debt (Environmental Protection Agency, 2018c). Expansions to these funding sources have been considered and include an expansion of the DWSRF and the creation of a National Infrastructure Bank (Baird, 2010).

An understanding of these trends in infrastructure costs and the means with which to

(C)Southern Regional Science Association 2019. 


\section{Figure 1: Spending on Infrastructure (Billions of 2014 Dollars}

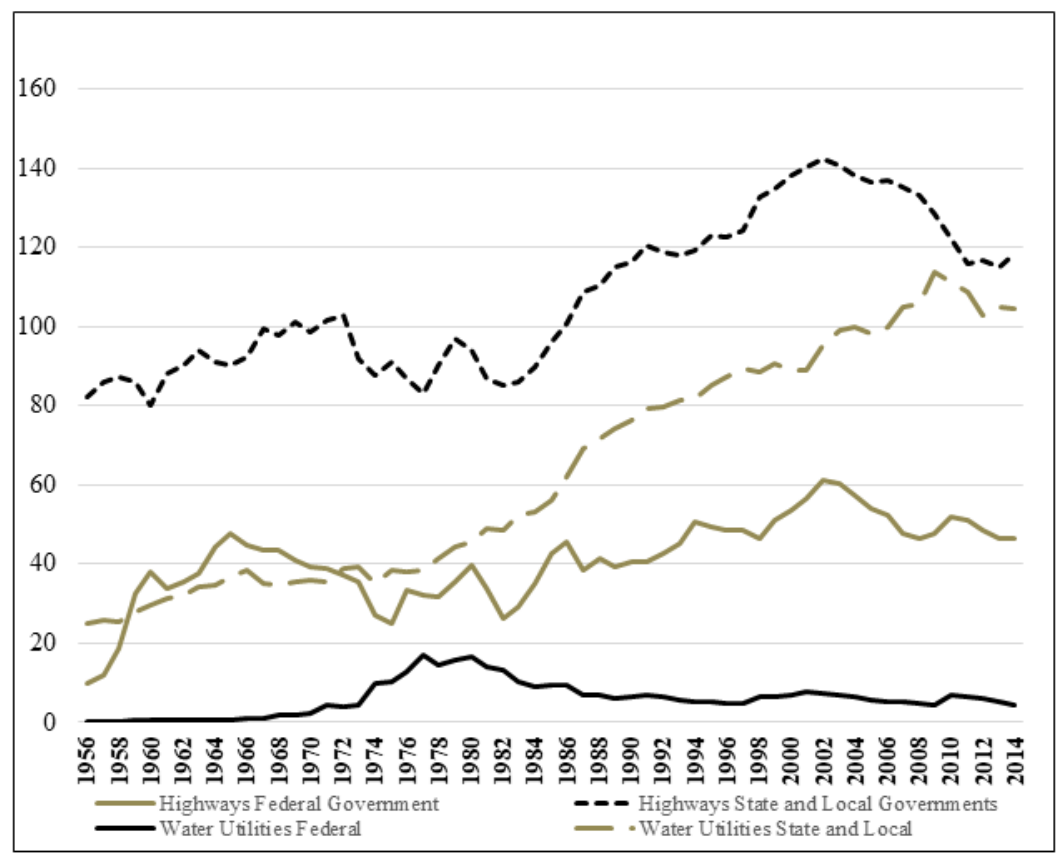

Source: Congressional Budget Office (CBO), 2015.

finance them is important because the current gap in financing means an increase in the cost of service for consumers (Forer and Staub, 2013). Ideally, as costs rise, the implementation of rate hikes will take place over time; however, a gradual rise may not be possible if infrastructure needs are to be met in the coming years (Baird, 2010). It is also unlikely that customers will dramatically cut water use if prices rise, given the relatively inelastic demand for water (Food and Water Watch, 2010). The EPA estimates that the demand elasticity of residential customers is between -0.2 and -0.4 and that the elasticity of demand for industrial customers is somewhere between -0.5 and -0.8 (Environmental Protection Agency, 2017). Consumers could also choose to take out additional debt to accommodate water prices, but studies suggest that household debt is already at an all-time high (Kim, 2018).

These high debt levels and inelastic demand for water could mean that households will change their spending patterns to accommodate higher water rates. Unfortunately, little information is available about potential changes in spending patterns. However, studies of consumer responses to recessions do provide some clues. Prior research finds that, during recessions, consumers shift spending away from non-essential goods, such as eating out, home furnishings and appliances, and recreation (Kamakura and Yuxing Du, 2011).

Data from the most recent recession highlights that the 2008 crisis had long-lasting impacts on consumer spending habits (The Economist, 2011). Consumers now spend less on items like eating out and new automobiles, and more money on utilities, fuels, and public services (The Economist, 2011). A Pew study of spending with respect to the last recession found that 62 percent of American cut back spending and 31 percent believe they 
will continue to spend less (Pew Research Center, 2010).

These changes could have cascading implications for household spending given prior work on consumer spending behavior. Studies have found that increased spending by high-income people can provoke an increase in spending in other income groups (Frank et al., 2010). Conversely, studies have found that these expenditure cascades can work in the opposite direction. Flatters and Willmott (2009) found that recessions can provoke a need for thriftier living in lower income groups, which then trickles up to higher income groups.

How changes in spending translate to rising water rates is unclear at this time. That said, there may be a way to develop changes in spending using this body of work on consumer responses to recessions and expenditure data from government sources. The remainder of this paper will outline a methodology for creating estimates of consumer responses to rising water prices, as well as estimated regional impacts of these spending changes.

\section{DATA}

To make these connections, this study will link data from the Consumer Expenditure Survey to input-output data from IMPLAN to project how consumers may alter spending behavior due to rising water prices and what this means for regional vitality in terms of income, jobs, value added and output.

\subsection{Consumer Expenditure Survey}

A good source of information about consumer spending on water services is the Bureau of Labor Statistics (BLS) Consumer Expenditure Survey (CES). This is a household survey used to understand how people spend money; it contains a variety of information about consumer expenditures, ranging from food to housing to television (Bureau of Labor Statistics, 2018b). In addition to pure expenditure characteristics, data are also collected about consumer characteristics, including age, race, income, educational attainment, and geographic region. Data are also provided for select metropolitan areas. While the coverage of metropolitan areas varies over time, ${ }^{3}$ it does provide a reasonable sample of expenditure data across the country.

It is also important to note that these data are the only federal source of consumer expenditure information (Bureau of Labor Statistics, 2018b). If one wanted to obtain household estimates on water services expenditures, it would be necessary to collect individual bills from a representative sample of households or collect rate data from individual water and sewer entities and compute an estimated bill for various levels of usage. For a fee, rate data are available via an annual survey conducted by the American Waterworks Association (AWWA). In the absence of these data, this paper develops a methodology to use the BLS CES data to create an estimate of expenditure decreases given a projected rise in water prices. These projected decreases are then linked to input-output data to create a projection of the regional economic impact of various water price increase scenarios for the three-county

\footnotetext{
3 "CE estimates are available for 26 selected MSAs from 1986 to 1995, for 28 MSAs from 1996 to 2004, for 24 MSAs in 2005, for 18 MSAs from 2006 to 2014, for 16 MSAs in 2015, and for 22 MSAs in 2016" (Bureau of Labor Statistics, 2018b).
}

(C)Southern Regional Science Association 2019. 
area in Arizona containing Maricopa, Pima, and Pinal counties. Maricopa County contains the city of Phoenix, Pima the city of Tucson, and Pinal the city of Casa Grande. To understand water expenditures in this region of the country, data were collected for the Phoenix MSA for a thirteen-year period 2004-2016. This period includes the pre-2008 boom, the 2008 recession, and the post-recession recovery period. Thus, it presents good longitudinal information about water expenditures over periods of economic expansion and contraction.

\subsection{Input-output Data}

To use the Phoenix metropolitan area data collected from the CES in a Multi-Regional InputOutput (MRIO) model, input-output data were also obtained for Maricopa, Pinal, and Pima counties from IMPLAN, a private company that produces annual estimates of input-output (IO) tables for the U.S. Input-output data are an accounting system for tracking the flows of purchases and sales within a regional economy (Isard et al., 2017). From a transactions table, a series of tables are generated via matrix algebra to create a total requirements table, the row sums of which provide assessments of economic impacts on output for a given change in final demand. Estimates of economic impacts on income and employment are derived by multiplying the elements of the total requirements table by labor input coefficients (specified in terms of income) and physical labor coefficients (specified in terms of employment to output ratios), to generate income and employment multipliers, respectively (Isard et al., 2017).

Input-output models are a popular tool for examining the impact of a range of water issues on regional economies. In the past, this type of model has been used to identify key water using sectors of the economy (Duarte et al., 2002), and the economic impacts of both technical improvements in water use and water price increases (Llop, 2008). More recently, computable general equilibrium models have been used to analyze the linkages between water prices, water conservation, and economic growth (Zhao et al., 2016). IMPLAN-based IO data have also been used to estimate the regional economic impacts of water cooperatives (Deller et al., 2009) and to estimate the employment impacts of recreational water use along the Colorado River (Douglas and Harpman, 1995). To date, however, there is scant evidence of U.S. oriented studies that use the utility of input-output models to analyze the regional economic impacts of aggregate household expenditure changes in response to rising water prices.

\section{METHODOLOGY}

To create a forecast for the regional economic impact of rising water expenditures in southern Arizona, two factors must first be obtained: 1) future projections for various scenarios of rising water prices (and thus expenditures ${ }^{4}$ ), and 2) an estimate of the decrease in average household spending in specific economic sectors given a projected water price increase. The

\footnotetext{
${ }^{4}$ In this study, we generally assume that the price of water utilities = average household expenditure on water utilities; thus "price" and "expenditure" are used interchangeably in this context. Generally, the data of interest are on expenditures, since those are measured spending patterns that can be used for economic impact analysis, but projections are often presented as average (per year) price increases.
}

(c) Southern Regional Science Association 2019. 
Figure 2: Price Trend Comparison of Household Budget Items

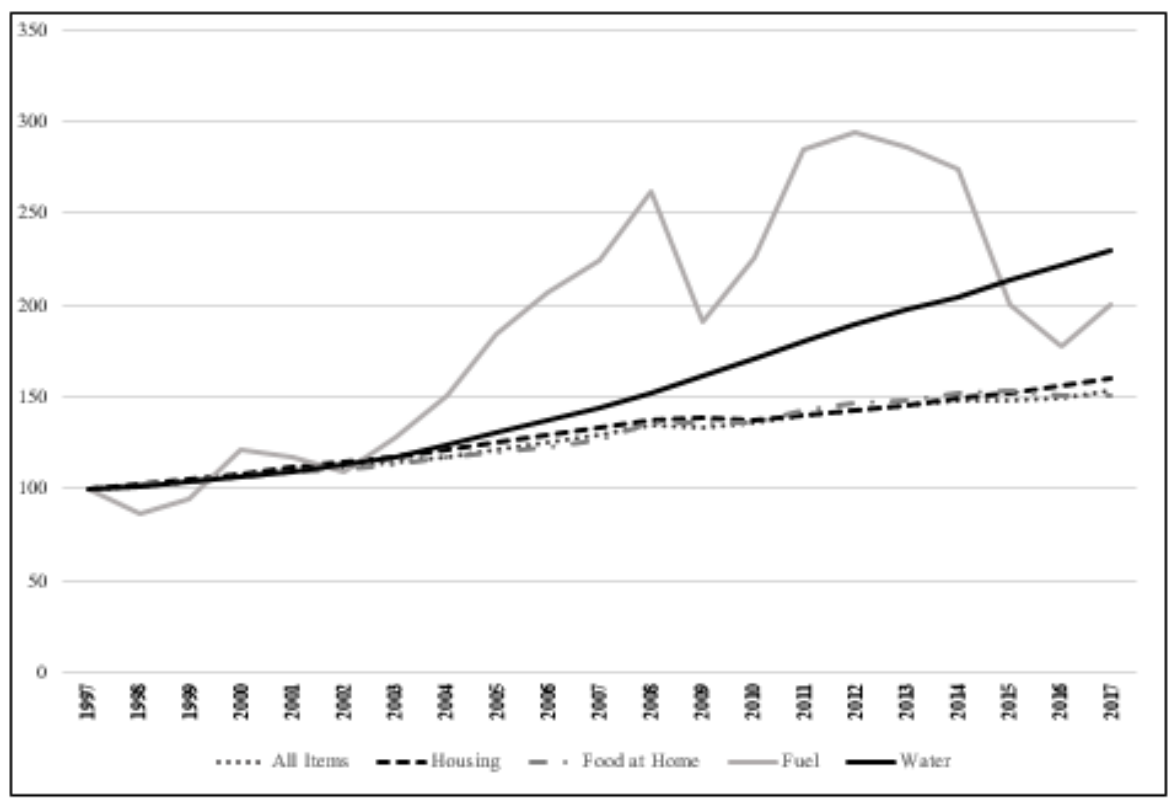

Source: Bureau of Labor Statistics, Consumer Price Index Data

resulting values - decreased household spending in specific sectors - are then aggregated from the household to the regional level and entered into a Multi-Regional Input-Output (MRIO) model to calculate the aggregate economic impacts of projected water price increases.

\subsection{Projecting Future Water Prices}

Estimating future water prices is a difficult task due to the range of projections of future water rates and the geographic variability in water price trends. Despite this difficulty, there are some data points that can help us project what future prices will look like. One source of information is the Consumer Price Index (CPI) for "Water and Related Services." Figure 2 displays the CPIs from the BLS for "Water and Related Services," "Fuel," "Food at Home," and "Housing." The CPI for all goods for all urban consumers is also included. This figure shows that water prices, compared to the other categories, have risen steadily over the last 20 years. On average, the CPI for water and related services increased by 4 percent per year compared to 2 percent for food, housing, and all items collectively. This amounts to a nearly $\$ 40$ increase over the past five years. The largest one-year increase in water prices occurred in 2009 and 2010.

For this paper, three price increase scenarios are used: a "baseline" projection $\left(P \_B A S E\right)$ based on historical water expenditure trends in Phoenix from 2004-2016 (Bureau of Labor Statistics, 2018a), a "middle" projection (P_MID) based on the CPI (Bureau of Labor Statistics, 2018a), and a "high" projection $\left(P_{-} H I G H\right)$ based on data collected by the water organization "Circle of Blue" (Walton, 2015). The baseline projection is created by obtaining 
Phoenix MSA expenditure data from the CES, which is provided for every year from 20042016 (Bureau of Labor Statistics, 2018b). At the national level, average expenditures on "water and other public services" is provided under the aggregated category "utilities, fuels, and public services;" however, at the MSA level, only data on the larger "utilities, fuels, and public services" category is available. In order to provide an MSA-specific estimate of water expenditures per year, all expenditures are first inflated to 2017 dollars using the CPI. Then, the national percentage of total utility expenditure spent on water in each year is calculated to create a "national water factor" in each year. This factor is then multiplied by the Phoenix total utility expenditure to provide a Phoenix-specific estimate of water expenditures in each year. The average annual increase from 2004-2016 is then calculated, yielding an average increase of $\$ 15.19$ per year, or 3.02 percent. This value is higher than the national average annual increase (in 2017 dollars) over the same time period of $\$ 12.11$ per year (2.43 percent).

This regional average increase contrasts with two other projections of price increases. First, data from the CPI for "water and sewer and trash collection services" 1997 to 2017 show the average yearly increase to be 4.23 percent, which, for the purposes of this study is rounded to 4 percent (Bureau of Labor Statistics, 2018a). Finally, the website "Circle of Blue" collected "water, sewer, and stormwater" prices for households in 30 select regions and found a 6 percent increase between 2014-2015, as well as a 41 percent total increase between 2010-2015 (Walton, 2015). While this 6 percent estimate (used in this paper) is not representative of the entire country, it does provide a realistic upper bound for water price increases for the present analysis. The percent increase in water for each scenario is displayed in Table 1.

\subsection{Projections of Consumer Expenditure Trends}

To estimate the relationship between projected water price increases in each scenario and the corresponding reductions in household spending in other budget categories, information about potential offsetting reductions in household spending was also obtained from the same time series of Phoenix expenditure data. Declines in consumer spending are anticipated based on prior studies of water affordability (Beecher and Shanaghan, 1998). Previous research also suggests that water expenditure increases likely lead to decreased spending in other areas, given the fact that elasticity of demand for water is relatively inelastic (Yoo et al., 2014), and the assumption that households will not incur debt to pay for rising water prices, given the record levels of household debt (Kim, 2018).

In order to provide an empirical estimate of the relationship, correlations are run between the water expenditure category and each of the other aggregate expenditure categories; the results of these correlations are shown in Table 1. This table highlights that positive correlations are generally observed for budget categories dealing with basic living expenses (shelter, other utilities, household operations, gasoline, public transit, healthcare, education, and insurance), i.e., items with relatively inelastic demand. In the expenditure data, entertainment is the only category positively-correlated with water expenditures that contradicts this trend. All of the other (more discretionary) categories display a negative correlation with water, as our intuition suggests.

(C)Southern Regional Science Association 2019. 
Table 1: Estimated Decreased Expenditures by Category Based on Regression Results for Water Price Increase Projections

\begin{tabular}{|c|c|c|c|c|c|c|c|c|c|c|}
\hline \multirow{3}{*}{$\begin{array}{l}\text { CES } \\
\text { expenditure } \\
\text { category }\end{array}$} & \multirow[b]{3}{*}{$\mathrm{r}$} & \multirow[b]{3}{*}{$\beta$} & \multirow[b]{3}{*}{$\mathrm{p}$-value } & \multirow[b]{3}{*}{$\mathrm{R}^{2}$} & \multicolumn{6}{|c|}{ Water price increase projections (per year) } \\
\hline & & & & & \multicolumn{2}{|c|}{ Baseline } & \multicolumn{2}{|c|}{ Middle } & \multicolumn{2}{|c|}{ High } \\
\hline & & & & & No. & Per. & No. & Per. & No. & Per. \\
\hline $\begin{array}{l}\text { Water \& other } \\
\text { public services }\end{array}$ & 1.00 & & & & $\$ 15.19$ & $3.02 \%$ & $\$ 24.61$ & $4.00 \%$ & $\$ 36.92$ & $6.00 \%$ \\
\hline Food at home & -0.115 & & & & & & & & & \\
\hline $\begin{array}{l}\text { Food away } \\
\text { from home }\end{array}$ & -0.565 & -0.101 & 0.004 & 0.320 & $-\$ 0.86$ & & $-\$ 1.39$ & & $-\$ 2.09$ & \\
\hline Alcohol & -0.445 & -0.325 & 0.020 & 0.198 & $-\$ 2.76$ & & $-\$ 4.48$ & & $-\$ 6.72$ & \\
\hline Shelter & 0.144 & & & & & & & & & \\
\hline $\begin{array}{l}\text { Non-water } \\
\text { utilities, fuels, } \\
\text { \& public services }\end{array}$ & & & & & & & & & & \\
\hline $\begin{array}{l}\text { \& public services } \\
\text { Household }\end{array}$ & 0.670 & & & & & & & & & \\
\hline operations & 0.425 & & & & & & & & & \\
\hline Housekeeping & -0.233 & & & & & & & & & \\
\hline Furniture & -0.472 & -0.067 & 0.051 & 0.223 & $-\$ 0.57$ & & $-\$ 0.92$ & & $-\$ 1.38$ & \\
\hline Apparel & -0.479 & -0.086 & 0.037 & 0.229 & $-\$ 0.73$ & & $-\$ 1.18$ & & $-\$ 1.77$ & \\
\hline $\begin{array}{l}\text { Vehicle } \\
\text { purchases }\end{array}$ & -0.830 & -0.029 & 0.004 & 0.689 & $-\$ 0.25$ & & $-\$ 0.40$ & & $\$ 0.60$ & \\
\hline Gas & 0.320 & & & & & & & & & \\
\hline $\begin{array}{l}\text { Other vehicle } \\
\text { expenses }\end{array}$ & -0.699 & -0.118 & 0.013 & 0.488 & $-\$ 1.00$ & & $-\$ 1.63$ & & $-\$ 2.44$ & \\
\hline Public transit & 0.273 & & & & & & & & & \\
\hline Healthcare & 0.279 & & & & & & & & & \\
\hline Entertainment & 0.387 & & & & & & & & & \\
\hline Personal care & -0.238 & & & & & & & & & \\
\hline Reading & -0.538 & -1.061 & 0.068 & 0.290 & $-\$ 9.02$ & & $-\$ 14.62$ & & $-\$ 21.92$ & \\
\hline Education & 0.075 & & & & & & & & & \\
\hline Tobacco & -0.463 & & & & & & & & & \\
\hline Miscellaneous & -0.515 & & & & & & & & & \\
\hline Cash & & & & & & & & & & \\
\hline contributions & -0.518 & & & & & & & & & \\
\hline Insurance & 0.030 & & & & & & & & & \\
\hline Total & & & & & $-\$ 15.19$ & & $-\$ 24.61$ & & $-\$ 36.92$ & \\
\hline
\end{tabular}

Given these observed negative correlations in specific categories, the task is to isolate statistically significant relationships between water expenditures and each of the other negatively-correlated expenditure categories' regressions (estimated with robust standard errors):

$$
Y=\beta_{i} X_{i}+\epsilon
$$

where $Y$ is water expenditure by year and $X_{i}$ is the vector of yearly observations of expenditures in each of the negatively-correlated expenditure categories $i$. Here it is important to note that we are interested in examining the impact of spending reductions on regional economies, which is why this analysis focuses on negative coefficient estimates.

Table 1 shows the coefficient, $\mathrm{p}$-value, and $\mathrm{R}^{2}$ values for each of the significant expendi- 
ture categories of interest, ${ }^{5}$ which include "food away from home," "alcohol," "furniture," "apparel," "vehicle purchases," "other vehicle expenses," and "reading." The coefficient values represent decreases in expenditures on a given category corresponding to a $\$ 1$ increase in expenditures, not controlling for any other factors ${ }^{6}$ - as such, the coefficients need to be normalized to correspond directly to each of the projected water price increases, preserving the relative magnitude of each coefficient. This normalization is calculated as follows:

$$
f_{i}=P_{s} \frac{\beta_{i} P_{s}}{\sum_{i} \beta_{i}}
$$

where $f_{i}$ is the normalized decrease (or final demand shock) for each expenditure category $i$, $\beta_{i}$ is the simple regression coefficient for expenditure category $i$, and $P_{s}$ is the projected yearly price increase in water for a given projection scenario $s$. This normalization is necessary, because the coefficients were obtained from individual regressions. So, if these coefficients are added, they will sum up to more than the projected water price increase obtained in the section above. To retain the relative magnitude of the coefficient for each significant expenditure category, they are normalized to sum to the projected water price increase. An implicit assumption of this normalization is that consumers will change expenditures to exactly offset price increases.

As Table 1 shows, $\$ 15.19$ is the observed yearly value for $P_{B A S E}$; since the middle and high projections used in this analysis are expressed as percentages, these percentages are multiplied by the Phoenix water expenditure value in 2016 to yield $\$ 24.61$ for $P_{M I D}$ and $\$ 36.92$ for $P_{\text {HIGH }}$. As shown in Table 1 , summing all $f_{i}$ equals the $P_{s}$ value for a given scenario.

\subsection{Forecasting Regional Economic Impacts}

Using the methods above, we obtained empirically-derived one-year decreases in household expenditures for each of the three water price trend scenarios. The expenditure assessment provides information about potential changes in household expenditures, on average, but there are wider regional implications of aggregate changes in household spending in response to water price increases. To understand the broader implications of these household responses, expenditures were aggregated to the county level to model changes in spending via a multi-regional input-output modeling (MRIO) framework.

The first step in this portion of the analysis is to match the CES expenditure categories to North American Industrial Classification System (NAICS) 440 sectors provided by IMPLAN, as no direct comparison exists. Matches are made only to similar categories in the tertiary

\footnotetext{
${ }^{5}$ Expenditures in the "tobacco," "miscellaneous," and "cash contributions" categories were shown to be statistically-significant but were excluded from the analysis due to the fact that decreases in spending in these are either unlikely to be related to water price increases (e.g., tobacco), or cannot be directly measured in the MRIO framework.

${ }^{6}$ Regressions including multiple variables, including a time dummy to control for, e.g., the decreasing acceptance of smoking, were also tried, but given the high collinearity between each of the expenditure variables of interest and time, individual expenditure decreases often became insignificant when controlling for other factors, yielding this kind of model ineffective for the purposes of this study.
}

(c) Southern Regional Science Association 2019. 
sector, since the final demand shocks modeled in this framework consist only of household expenditures on final goods and services. This is because households buy goods only from retailers - not intermediary suppliers or wholesalers - so final demand shocks must be entered in "final" consumer goods sectors. The connections built into the IO framework then model the ripple effects of final demand shock through all sectors of the economy.

Table 2 shows the matched sectors for each expenditure category. Weights are assigned to expenditure categories that cross two or more IMPLAN 440 sectors; for instance, the CES category "other vehicle expenses" matches to the sectors "automotive repair and maintenance, except car washes" and "car washes" - so weights of .75 and .25, respectively, are applied to divide the total CES expenditure between these two categories. The weighted per household spending in each IMPLAN sector is then multiplied by the 2010 number of households (provided in the data) for each of the three counties in southern Arizona: Maricopa, Pima, and Pinal, for each of the three scenarios. Table 2 shows the aggregated values for Maricopa County only. Here it is important to note that these figures were converted from consumer to producer prices using margins in IMPLAN. ${ }^{7}$

These values were entered into a MRIO model using IMPLAN version 3.1. Traditional input-output ( $\mathrm{I}-\mathrm{O}$ ) models are created based on an underlying matrix of purchases that each sector makes from every other sector (Isard et al., 2017). This transactions table is used to create a direct requirements matrix:

$$
A=\begin{array}{ccc}
a_{1,1} & \ldots & a_{1, n} \\
\cdot & \cdot & \cdot \\
\cdot & \cdot & \cdot \\
\cdot & \cdot & \cdot \\
a_{n, 1} & \ldots & a_{n, n}
\end{array}
$$

in which $a_{i j}=z_{i j} / x_{j}$, where $z_{i j}$ is the value of inputs purchased by industry $j$ from industry $i$, and $x_{j}$ is the total of all inputs purchased by sector $j$. Final demand (or economic shocks) in each sector can be modeled as a function of this direct requirements matrix (Isard et al., 2017). In this paper, the $f$ matrix is taken from Equation (2), which provides the method for deriving final demand shocks to be modeled using the MRIO framework. This matrix is specified as follows:

$$
\mathbf{f}=(\mathbf{I}-\mathbf{A}) \mathbf{x}
$$

where $\mathbf{f}$ is a matrix of final demand figures in each sector $i, \mathbf{I}$ is an identity matrix, and $\mathbf{x}$ is a matrix of total output for each sector $i$. In a situation where $\mathbf{I}, \mathbf{A}$, and $\mathbf{f}$ are known, as is the case here, the equation can be re-written to solve for the final outputs $(\mathbf{x})$ in each sector given a specific set of final demand shocks $(\mathbf{f})^{8}$ :

\footnotetext{
${ }^{7}$ Margins were applied to the following IMPLAN industries: $320,321,324,327$, and 328 . In IMPLAN margins may not be applied to services based industries. In the vector of final demand, margins were not applied to the following services industries: 413, 414, and 415.

${ }^{8}$ In this paper, the $\mathbf{f}$ matrix is taken directly from Equation (2), which provides the method for deriving final demand shocks to be modeled using the MRIO framework. These direct decrease values, i.e., the $\mathbf{f}$ matrix used for each scenario, are shown in Table 3.
}

(c)Southern Regional Science Association 2019. 
Table 2: Aggregate Expenditure Decreases for Each Scenario Translated to IMPLAN 440 Sectoring Scheme

\begin{tabular}{|c|c|c|c|c|c|}
\hline \multirow[t]{3}{*}{$\begin{array}{l}\text { CES } \\
\text { Category }\end{array}$} & \multirow[t]{3}{*}{$\begin{array}{l}\text { IMPLAN } \\
440 \text { Codes }\end{array}$} & \multirow[t]{3}{*}{ IMPLAN 440 Description } & \multirow[t]{3}{*}{$\begin{array}{l}\text { Category } \\
\text { Weight }\end{array}$} & \multicolumn{2}{|c|}{$\begin{array}{c}\text { Aggregate Demand } \\
\text { Spending (per year) }(\mathbf{f})\end{array}$} \\
\hline & & & & $\begin{array}{l}\text { Weighted } \\
\text { per HH } \\
\text { Spending }\end{array}$ & $\begin{array}{c}\text { Weighted Total } \\
\text { Spending } \\
\text { (Maricopa) }\end{array}$ \\
\hline & & & & \multicolumn{2}{|r|}{ Baseline } \\
\hline $\begin{array}{l}\text { Food away } \\
\text { from home }\end{array}$ & 413 & Food services and drinking places & 1 & $-\$ 0.86$ & $-\$ 1,223,833.76$ \\
\hline \multirow{2}{*}{ Alcohol } & 413 & Food services and drinking places & 0.5 & $-\$ 1.38$ & $-\$ 1,970,182.85$ \\
\hline & 324 & Retail Stores - food and beverage & 0.5 & $-\$ 1.38$ & $-\$ 1,970,182.85$ \\
\hline Furniture & 321 & Retail Stores: furniture \& home furnishings & 1 & $-\$ 0.57$ & $-\$ 808,706.69$ \\
\hline Apparel & 327 & Retail Stores: clothing \& clothing accessories & 1 & $-\$ 0.73$ & $-\$ 1,036,506.03$ \\
\hline $\begin{array}{l}\text { Vehicle } \\
\text { purchases }\end{array}$ & 320 & Retail Stores - motor vehicle and parts & 1 & $-\$ 0.25$ & $-\$ 353,679.66$ \\
\hline \multirow{2}{*}{$\begin{array}{l}\text { Other vehicle } \\
\text { expenses }\end{array}$} & 414 & $\begin{array}{l}\text { Automotive repair and maintenance, except } \\
\text { car washes }\end{array}$ & 0.75 & $-\$ 0.75$ & $-\$ 1,072,559.68$ \\
\hline & 415 & Car washes & 0.25 & $-\$ 0.25$ & $-\$ 357,519.89$ \\
\hline Reading & 328 & $\begin{array}{l}\text { Retail Stores - sporting goods, hobby, book } \\
\text { and music }\end{array}$ & 1 & $-\$ 9.02$ & $-\$ 12,853,041.98$ \\
\hline \multirow[t]{2}{*}{ Total } & & & & $-\$ 15.19$ & $-\$ 21,646,213.40$ \\
\hline & & & & \multicolumn{2}{|c|}{ Middle } \\
\hline $\begin{array}{l}\text { Food away } \\
\text { from home }\end{array}$ & 413 & Food services and drinking places & 1 & $-\$ 1.39$ & $-\$ 1,983,197.35$ \\
\hline \multirow{2}{*}{ Alcohol } & 413 & Food services and drinking places & 0.5 & $-\$ 2.24$ & $-\$ 3,192,640.64$ \\
\hline & 324 & Retail Stores - food and beverage & 0.5 & $-\$ 2.24$ & $-\$ 3,192,640.64$ \\
\hline \multirow{3}{*}{$\begin{array}{l}\text { Furniture } \\
\text { Apparel } \\
\text { Vehicle } \\
\text { purchases }\end{array}$} & 321 & Retail Stores: furniture \& home furnishings & 1 & $-\$ 0.92$ & $-\$ 1,310,492.49$ \\
\hline & 327 & Retail Stores: clothing \& clothing accessories & 1 & $-\$ 1.18$ & $-\$ 1,679,636.62$ \\
\hline & 320 & Retail Stores - motor vehicle and parts & 1 & $-\$ 0.40$ & $-\$ 573,130.58$ \\
\hline \multirow{2}{*}{$\begin{array}{l}\text { Other vehicle } \\
\text { expenses }\end{array}$} & 414 & $\begin{array}{l}\text { Automotive repair and maintenance, except } \\
\text { car washes }\end{array}$ & 0.75 & $-\$ 1.22$ & $-\$ 1,738,060.82$ \\
\hline & 415 & Car washes & 0.25 & $-\$ 0.41$ & $-\$ 579,353.61$ \\
\hline Reading & 328 & $\begin{array}{l}\text { Retail Stores - sporting goods, hobby, book } \\
\text { and music }\end{array}$ & 1 & $-\$ 14.62$ & $-\$ 20,828,089.15$ \\
\hline \multirow[t]{2}{*}{ Total } & & & & $-\$ 24.61$ & $-\$ 35,077,241.89$ \\
\hline & & & & & High \\
\hline $\begin{array}{l}\text { Food away } \\
\text { from home }\end{array}$ & 413 & Food services and drinking places & 1 & $-\$ 2.09$ & $-\$ 2,974,796.02$ \\
\hline \multirow{2}{*}{ Alcohol } & 413 & Food services and drinking places & 0.5 & $-\$ 3.36$ & $-\$ 4,788,960.95$ \\
\hline & 324 & Retail Stores - food and beverage & 0.5 & $-\$ 3.36$ & $-\$ 4,788,960.95$ \\
\hline \multirow{3}{*}{$\begin{array}{l}\text { Furniture } \\
\text { Apparel } \\
\text { Vehicle } \\
\text { purchases }\end{array}$} & 321 & Retail Stores: furniture \& home furnishings & 1 & $-\$ 1.38$ & $-\$ 1,965,738.73$ \\
\hline & 327 & Retail Stores: clothing \& clothing accessories & 1 & $-\$ 1.77$ & $-\$ 2,519,454.93$ \\
\hline & 320 & Retail Stores - motor vehicle and parts & 1 & $-\$ 0.60$ & $-\$ 859,695.88$ \\
\hline \multirow{2}{*}{$\begin{array}{l}\text { Other vehicle } \\
\text { expenses }\end{array}$} & 414 & $\begin{array}{l}\text { Automotive repair and maintenance, except } \\
\text { car washes }\end{array}$ & 0.75 & $-\$ 1.83$ & $-\$ 2,607,091.24$ \\
\hline & 415 & Car washes & 0.25 & $-\$ 0.61$ & $-\$ 869,030.41$ \\
\hline Reading & 328 & $\begin{array}{l}\text { Retail Stores - sporting goods, hobby, book } \\
\text { and music }\end{array}$ & 1 & $-\$ 21.92$ & $-\$ 31,242,133.73$ \\
\hline Total & & & & $-\$ 36.92$ & $-\$ 52,615,862.84$ \\
\hline
\end{tabular}

$$
\mathrm{x}=(\mathrm{I}-\mathrm{A})^{-1} \mathbf{f} .
$$

MRIO expands on the traditional I-O framework by linking each of the counties in a 
given region using data on goods shipments ${ }^{9}$ between the counties (Isard et al., 2017). In this case, $z_{i}^{\mathrm{LM}}$ represents the amount of goods $(z)$ sold by sector $i$ that are shipped from county $L$ to county $M ; z_{i}{ }^{\mathrm{LL}}$ is the amount of goods shipped within county $L$. These numbers can then be used to find the proportion of goods shipped to/from each county, i.e., $t_{i}{ }^{\mathrm{LM}}$ and $t_{i}^{\mathrm{LL}} \cdot{ }^{10}$

The essence of the MRIO model is to insert these trade coefficients (for each industry) into the original I-O structure, thus creating a new set of county origin-destination specific A matrices:

$$
\begin{aligned}
& t_{1}{ }^{\mathrm{LL}} a_{1,1} \cdot \mathrm{L} \quad \ldots \quad t_{1}{ }^{\mathrm{LL}} a_{1, n}{ }^{. \mathrm{L}} \\
& A^{\mathrm{LL}}=\quad \cdot \quad \cdot \cdot \\
& t_{1}{ }^{\mathrm{LL}} \vec{a}_{n, 1} \cdot{ }^{\mathrm{L}} \quad{ }^{\cdot} \quad t_{1}{ }^{\mathrm{LL}} \dot{a}_{n, n}{ }^{. \mathrm{L}} \\
& t_{1}{ }^{\mathrm{LM}} a_{1,1} \cdot \mathrm{M} \quad \ldots \quad t_{1}{ }^{\mathrm{LM}} a_{1, n} \cdot \mathrm{M} \\
& A^{\mathrm{LM}}=\quad . \quad . \\
& t_{1}{ }^{\mathrm{LM}} \dot{a}_{n, 1}{ }^{\mathrm{M}} \quad \cdot t_{1}{ }^{\mathrm{LM}} \dot{a}_{n, n} . \mathrm{M} \\
& t_{1}{ }^{\mathrm{ML}} a_{1,1} . \mathrm{L} \quad \ldots \quad t_{1}{ }^{\mathrm{ML}} a_{1, n} . \mathrm{L} \\
& A^{\mathrm{ML}}=\quad \cdot \quad . \\
& t_{1}{ }^{\mathrm{ML}} a_{a_{n, 1} . \mathrm{L}} \quad \ldots \quad t_{1}^{\mathrm{ML}} a_{n, n} . \mathrm{L} \\
& t_{1}{ }^{\mathrm{MM}} a_{1,1} \cdot \mathrm{M} \quad \ldots \quad t_{1}^{\mathrm{MM}} a_{1, n}{ }^{. \mathrm{M}} \\
& A^{\mathrm{MM}}=\quad \cdot \quad \cdot \quad \cdot \cdot \\
& t_{1}{ }^{\mathrm{MM}} \dot{a}_{n, 1} \cdot \mathrm{M} \quad \ldots \quad t_{1}{ }^{\mathrm{MM}} \dot{a}_{n, n}{ }^{. \mathrm{M}}
\end{aligned}
$$

In the end, this means that in an MRIO model final demand shocks "f" are entered separately for each county in a region, e.g., $\mathbf{f}^{\mathrm{L}}$ and $\mathbf{f}^{\mathrm{M}}$, and changes in final output $\mathbf{x}$ are generated for all regional counties, e.g., $\mathbf{x}^{\mathbf{L}}$ and $\mathrm{x}^{\mathrm{M}}$, for each county-specific set of final demand shocks. This means that, to model total MRIO economic impacts in IMPLAN, linked models must be run with each of the three regional counties serving alternately as the primary county, and the total resulting impacts summed. In this paper, this is done for each of the three scenarios of interest.

Table 3 presents the final demand vectors for each of the three counties of interest in the analysis in terms of consumer prices. As described previously, the figures in these vectors were

\footnotetext{
${ }^{9}$ The national trade flows model was used to estimate shipments between counties.

${ }^{10} \mathrm{~A}$ concrete (simplified) example with only two counties: 50 units of all vehicles sold in Maricopa county are shipped to (or purchased by residents of) Pinal county, while 150 remain in Maricopa. In this case, $t_{i}{ }^{\mathrm{LM}}=50 / 200=.25$, and $t_{i}{ }^{\mathrm{LL}}=150 / 200=.75$.
} 
Table 3: Final Demand Vectors (f Matrices) for each County for each Water Price Increase Scenario

\begin{tabular}{|c|c|c|c|}
\hline Maricopa & Baseline & Middle & High \\
\hline Retail Stores: Motor vehicles and parts (320) & $-\$ 353,679.66$ & $-\$ 573,130.58$ & $-\$ 859,695.88$ \\
\hline Retail Stores: Furniture and & & & \\
\hline home furnishings (321) & $-\$ 808,706.69$ & $-\$ 1,310,492.49$ & $-\$ 1,965,738.73$ \\
\hline Retail Stores: Food and beverage (324) & $-\$ 1,970,182.85$ & $-\$ 3,192,640.64$ & $-\$ 4,788,960.95$ \\
\hline $\begin{array}{l}\text { Retail Stores: Clothing and clothing } \\
\text { accessories }(327)\end{array}$ & $-\$ 1,036,506.03$ & $-\$ 1,679,636.62$ & $-\$ 2,519,454.93$ \\
\hline $\begin{array}{l}\text { Retail Stores: Sporting goods, hobby, } \\
\text { book, and music }(328)\end{array}$ & $-\$ 12.853 .041 .98$ & $-\$ 20.828 .089 .15$ & $-\$ 31.242 .133 .73$ \\
\hline Food Services and drinking places (413) & $-\$ 1,223,833.76$ & $-\$ 1,983,197.35$ & $-\$ 2,974,796.02$ \\
\hline Food Services and drinking places (413) & $-\$ 1,970,182.85$ & $-\$ 3,192,640.64$ & $-\$ 4,788,960.95$ \\
\hline $\begin{array}{l}\text { Automotive repair and maintenance, } \\
\text { except car washes (414) }\end{array}$ & $-\$ 1,072,559.68$ & $-\$ 1,738,060.82$ & $-\$ 2,607,091.24$ \\
\hline Car washes (415) & $-\$ 357,519.89$ & $-\$ 579,353.61$ & $-\$ 869,030.41$ \\
\hline $\begin{array}{l}\text { Water, sewage, and other treatment } \\
\text { and delivery systems (33) }\end{array}$ & $\$ 21,646,213.40$ & $\$ 35,077,241.89$ & $\$ 52,615,862.84$ \\
\hline Pinal & & & \\
\hline $\begin{array}{l}\text { Retail Stores: Motor vehicles and parts (320) } \\
\text { Retail Stores: Furniture and }\end{array}$ & $-\$ 29,970.04$ & $-\$ 48,565.83$ & $-\$ 72,848.74$ \\
\hline home furnishings $(321)$ & $-\$ 68,528.03$ & $-\$ 111,048.26$ & $-\$ 166,572.39$ \\
\hline Retail Stores: Food and beverage (324) & $-\$ 166,948.97$ & $-\$ 270,537.36$ & $-\$ 405,806.04$ \\
\hline $\begin{array}{l}\text { Retail Stores: Clothing and clothing } \\
\text { accessories }(327)\end{array}$ & $-\$ 87,831.25$ & $-\$ 142,328.72$ & $-\$ 213,493.08$ \\
\hline $\begin{array}{l}\text { Retail Stores: Sporting goods, hobby, } \\
\text { book, and music }(328)\end{array}$ & $-\$ 1,089,138.58$ & $-\$ 1.764 .926 .58$ & $-\$ 2,647.389 .87$ \\
\hline Food Services and drinking places (413) & $-\$ 103,704.99$ & $-\$ 168,051.79$ & $-\$ 252,077.69$ \\
\hline Food Services and drinking places (413) & $-\$ 166,948.97$ & $-\$ 270,537.36$ & $-\$ 405,806.04$ \\
\hline $\begin{array}{l}\text { Automotive repair and maintenance, } \\
\text { except car washes (414) }\end{array}$ & $-\$ 90,886.35$ & $-\$ 147,279.46$ & $-\$ 220,919.19$ \\
\hline Car washes (415) & $-\$ 30,295.45$ & $-\$ 49,093.15$ & $-\$ 73,639.73$ \\
\hline $\begin{array}{l}\text { Water, sewage, and other treatment } \\
\text { and delivery systems (33) }\end{array}$ & $\$ 1,834,252.63$ & $\$ 2,972,368.52$ & $\$ 4,458,552.78$ \\
\hline Pima & & & \\
\hline $\begin{array}{l}\text { Retail Stores: Motor vehicles and parts (320) } \\
\text { Retail Stores: Furniture and }\end{array}$ & $-\$ 95,524.21$ & $-\$ 154,795.01$ & $-\$ 232,192.51$ \\
\hline home furnishings $(321)$ & $-\$ 218,421.00$ & $-\$ 353,946.72$ & $-\$ 530,920.09$ \\
\hline Retail Stores: Food and beverage (324) & $-\$ 532,120.39$ & $-\$ 862,290.10$ & -\$1,293,435.15 \\
\hline $\begin{array}{l}\text { Retail Stores: Clothing and clothing } \\
\text { accessories (327) }\end{array}$ & $-\$ 279,946.60$ & $-\$ 453,647.68$ & $-\$ 680,471.52$ \\
\hline $\begin{array}{l}\text { Retail Stores: Sporting goods, hobby, } \\
\text { book, and music }(328)\end{array}$ & $-\$ 3,471,437.00$ & $-\$ 5,625,391.98$ & $-\$ 8,438,087.97$ \\
\hline Food Services and drinking places (413) & $-\$ 330,541.35$ & $-\$ 535,635.43$ & $-\$ 803,453.14$ \\
\hline Food Services and drinking places (413) & $-\$ 532,120.39$ & $-\$ 862,290.10$ & $-\$ 1,293,435.15$ \\
\hline $\begin{array}{l}\text { Automotive repair and maintenance, } \\
\text { except car washes (414) }\end{array}$ & $-\$ 289,684.21$ & $-\$ 469,427.29$ & $-\$ 704,140.93$ \\
\hline Car washes (415) & $-\$ 96,561.40$ & $-\$ 156,475.76$ & $-\$ 234,713.64$ \\
\hline $\begin{array}{l}\text { Water, sewage, and other treatment } \\
\text { and delivery systems (33) }\end{array}$ & $\$ 5,846,356.54$ & $\$ 9,473,900.07$ & $\$ 14,210,850.10$ \\
\hline
\end{tabular}

(C)Southern Regional Science Association 2019. 
obtained by multiplying the coefficient estimates from Table 1 by the number of households in each county. In these final demand vectors, the additional spending on water services by consumers is recognized as a positive shock to the economy. While this additional spending could offset the rising cost of providing water services, particularly for public utilities who typically set prices at the cost of service (Food and Water Watch, 2016), it is important to recognize this infusion of funds to water providers. The cost recovery nature of water utilities discussed earlier indicates that funds collected by water providers from ratepayers will be distributed to other sectors by providers according to their specific costs and needs.

The results presented in the next section are regional economic impacts resulting from each of the three water price increase scenarios. In estimating these numbers, the event year was set to 2010 to match the year of the household data from IMPLAN, which was the basis for calculating the changes in final demand in the $\mathbf{f}$ matrix (see Table 3 ). Margins were applied to retail sectors to convert estimates of final demand shocks to producer prices. Estimated economic impacts are reported in 2017 dollars.

\section{RESULTS}

Before moving on to a discussion of the results, some trends for water expenditures in Phoenix will be discussed (Figure 3). In 2004, Phoenicians spent less than the national average on water and related services. Starting in 2007 however, outlays for water exceeded and remained above the national average. By 2016, residents in Phoenix were spending (on average) $\$ 615$ annually on water compared to only $\$ 586$ nationally. Spending on water also appears to be more volatile in this region than the nation as a whole, as indicated by large spikes in expenditures in 2009 and 2012. Studies indicate that water use in Arizona is declining (McGlade, 2015; Nicla, 2019). While this could reflect a desire to conserve water, it could also reflect efforts to reduce water costs because of rising prices. In fact, data for Phoenix indicate a rise in water prices between 2010-2011, 2012-2013, 2015-2016, as well as 2016-2017 (Walton, 2017). While this trend indicates greater proportions of household spending on water, the results of the multi-regional input-output models indicate that rising prices could have larger regional economic impacts.

Based on the three scenarios and associated change in final demand vectors (f matrices) described above, economic impacts for output, employment, and income were generated for the Phoenix-Tucson metropolitan area. Table 4 summarizes the total impacts for each of the three counties analyzed. The Appendix presents the full results broken down by direct, indirect, and induced impacts. Overall, analytical results show that total regional impacts from increased water prices result in a negative net decrease in jobs (-89 to -231). This is a fraction of total regional employment (between -0.003 percent and -0.008 percent) in 2010. That said, the types of jobs lost are important to characterize. Table 5 shows that while employment gains are made in sectors such as "maintenance and repair construction of nonresidential structures" and "architectural, engineering, and related services," the jobs lost are in service sectors such as food services and drinking places and real estate. ${ }^{11}$

\footnotetext{
${ }^{11}$ No negative employment induced effects were found in any price increase scenario for the results presented in Table 5
}

(c)Southern Regional Science Association 2019. 


\section{Figure 3: Consumer Expenditures on Water, 2004-2016 (2017 dollars)}

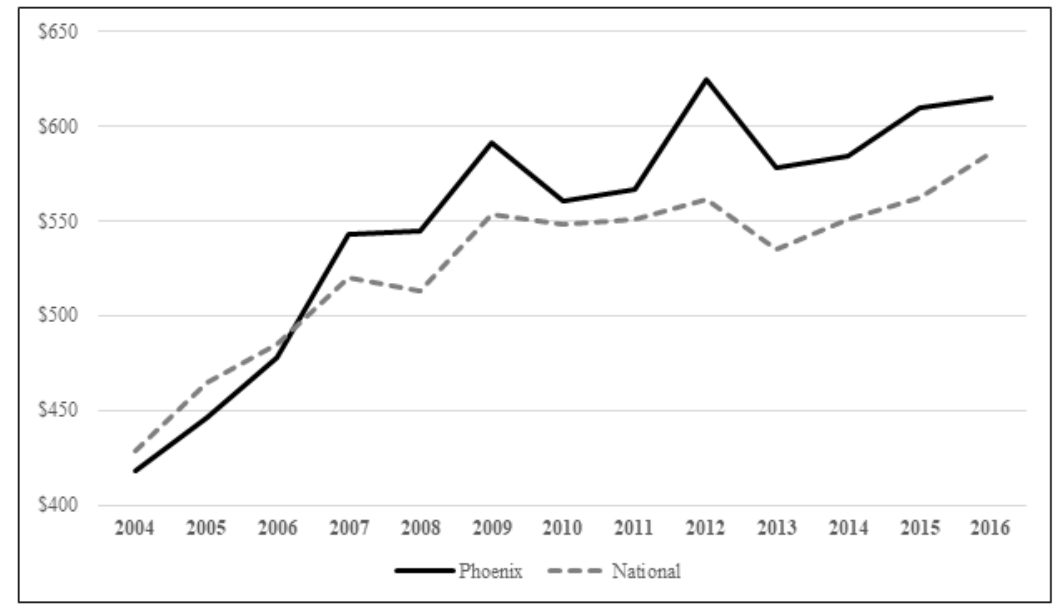

Source: Bureau of Labor Statistics Consumer Expenditure Survey

Table 4: Summary of Economic Impacts to Southern Arizona for Baseline, Middle, and High Water Price Increase Scenarios

\begin{tabular}{lcccc}
\hline \hline & Indicator & Baseline & Middle & High \\
\hline \multirow{5}{*}{ Direct Effects } & Employment & -150.1 & -243.1 & -361.2 \\
& Income & $\$ 4,905,650$ & $\$ 7,949,505$ & $\$ 11,780,302$ \\
& Value Added & $\$ 16,513,044$ & $\$ 26,759,046$ & $\$ 40,045,764$ \\
& Output & $\$ 14,363,083$ & $\$ 23,275,081$ & $\$ 34,912,622$ \\
\hline \multirow{5}{*}{ Indirect Effects } & Employment & 13.1 & 21.4 & 24.4 \\
& Labor Income & $\$ 1,147,714$ & $\$ 1,859,849$ & $\$ 2,331,503$ \\
& Value Added & $\$ 866,149$ & $\$ 1,403,577$ & $\$ 1,546,665$ \\
& Output & $\$ 2,397,942$ & $\$ 3,885,819$ & $\$ 4,673,665$ \\
\hline \multirow{5}{*}{ Induced Effects } & Employment & 47.7 & 77.4 & 106.6 \\
& Income & $\$ 2,282,938$ & $\$ 3,699,453$ & $\$ 5,170,324$ \\
& Value Added & $\$ 4,109,664$ & $\$ 6,659,627$ & $\$ 9,297,956$ \\
& Output & $\$ 6,406,030$ & $\$ 10,380,843$ & $\$ 14,422,769$ \\
\hline & Employment & -89.1 & -144.4 & -230.5 \\
& Income & $\$ 8,336,305$ & $\$ 13,508,808$ & $\$ 19,282,131$ \\
& Value Added & $\$ 21,488,857$ & $\$ 34,822,251$ & $\$ 50,890,388$ \\
& Output & $\$ 23,167,061$ & $\$ 37,541,745$ & $\$ 54,009,057$ \\
\hline \hline
\end{tabular}

(C)Southern Regional Science Association 2019. 


\section{Figure 4: Direct, Indirect, and Induced Employment Impacts by County for each Projected Water Price Increase Scenario}

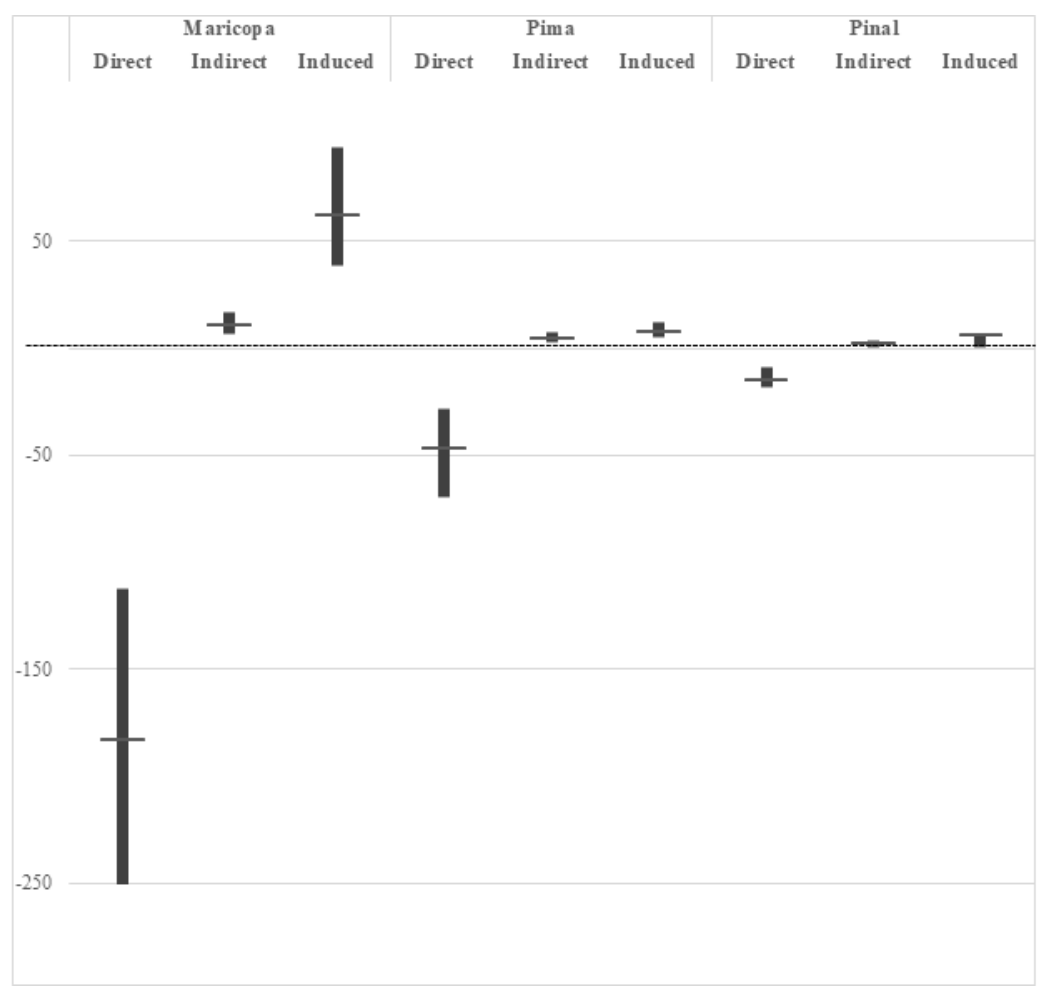

Geographically, Maricopa County has the largest total impacts and clearly drives the results of this analysis: in each scenario, this county accounts for about 70 percent of the impacts. This is in line with expectations since it is the largest county in the study region with over 4 million people in 2017 (U.S. Census Bureau, 2018). The relative size of these impacts across the three counties is illustrated for employment in Figure 4.

In terms of labor income, value added, and output, Table 4 and Figure 5 highlight that the net regional results of the water price increases are positive. This is a reflection of how the change in final demand matrix was generated. In this matrix, we assumed that payments by consumers to the water sector are a positive infusion of money into the system. These payments to the water sector are then recirculated to other sectors. Table 6 provides the multiplier detail for Maricopa County for three types of multipliers (output, labor income, and value added) for the industries most closely tied to the water sector as indicated by the magnitude of the multiplier numbers. Based on the multipliers, the industries most closely linked to water and sewer services are "maintenance and repair of nonresidential structures," "architectural and engineering services," and "accounting services." These interindustry linkages make sense given the discussion of costs drivers for water and wastewater utilities mentioned earlier which include capital expenditures for infrastructure repairs and expansions. 
Figure 5: Total Output, Employment, and Income Impacts from each Projected Water Price Increase Scenario

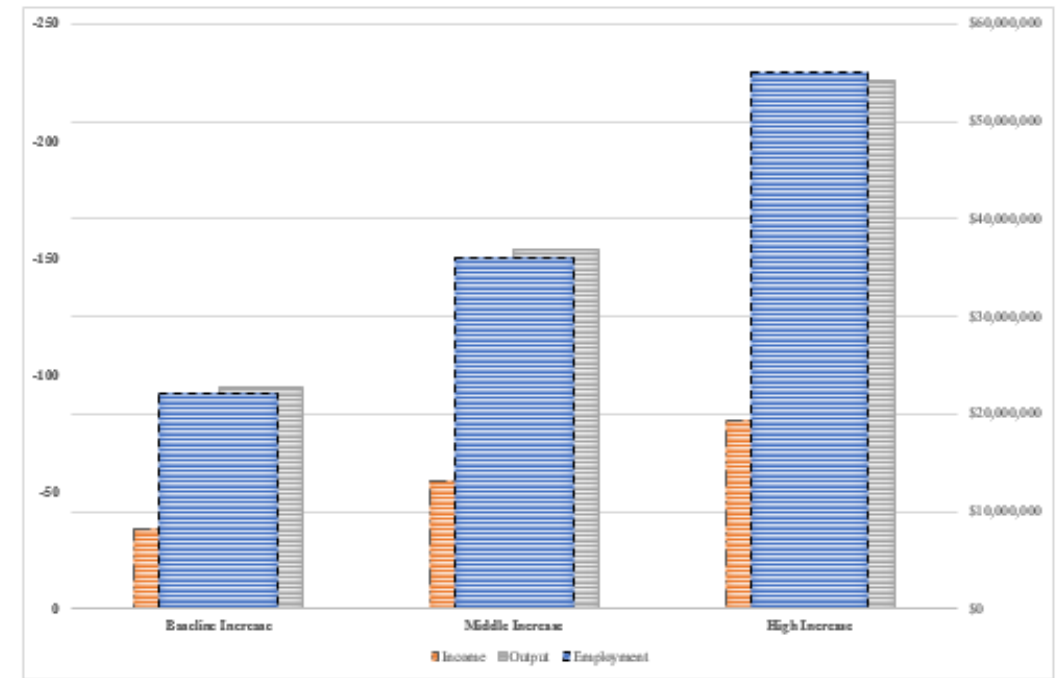

Employment effects (negative) shown on left axis; output and income effects (positive) shown on right axis.

Table 5: Employment Impacts to the Top and Bottom 5 Industries by Indirect Effects and for the Top 5 Industries by Induced Effects - for each Price Increase Scenario

\begin{tabular}{|c|c|c|c|c|c|}
\hline & & & Sector & Description & Emp. \\
\hline \multirow{15}{*}{ Baseline } & \multirow{10}{*}{ Indirect } & \multirow{5}{*}{ Top 5} & 39 & $\begin{array}{l}\text { Maintenance and repair construction } \\
\text { of nonresidential structures }\end{array}$ & 15.0 \\
\hline & & & 369 & Architectural, engineering, and related services & 6.0 \\
\hline & & & 368 & $\begin{array}{l}\text { Accounting, tax preparation, bookkeeping, and } \\
\text { payroll services }\end{array}$ & 5.5 \\
\hline & & & 367 & Legal services & 1.4 \\
\hline & & & 354 & $\begin{array}{l}\text { Monetary authorities and depository credit } \\
\text { intermediation activities }\end{array}$ & 0.8 \\
\hline & & \multirow{5}{*}{ Bottom 5} & 377 & Advertising and related services & -0.8 \\
\hline & & & 319 & Wholesale trade businesses & -0.8 \\
\hline & & & 381 & Management of companies and enterprises & -0.8 \\
\hline & & & 340 & Warehousing and storage & -1.1 \\
\hline & & & 360 & Real estate establishments & -4.0 \\
\hline & \multirow{5}{*}{ Induced } & \multirow{5}{*}{ Top 5} & 413 & Food services and drinking places & 4.9 \\
\hline & & & 360 & Real estate establishments & 2.8 \\
\hline & & & 394 & $\begin{array}{l}\text { Offices of physicians, dentists, and other health } \\
\text { practitioners }\end{array}$ & 2.4 \\
\hline & & & 397 & Private hospitals & 2.4 \\
\hline & & & 329 & Retail Stores - General merchandise & 1.6 \\
\hline
\end{tabular}


Table 5: continued from previous page

\begin{tabular}{|c|c|c|c|c|c|}
\hline & & & Sector & Description & Emp. \\
\hline \multirow{15}{*}{ Middle } & \multirow{10}{*}{ Indirect } & \multirow{5}{*}{ Top 5} & 39 & $\begin{array}{l}\text { Maintenance and repair construction } \\
\text { of nonresidential structures }\end{array}$ & 24.5 \\
\hline & & & 369 & Architectural, engineering, and related services & 9.8 \\
\hline & & & 368 & $\begin{array}{l}\text { Accounting, tax preparation, bookkeeping, and } \\
\text { payroll services }\end{array}$ & 9.1 \\
\hline & & & 367 & Legal services & 2.3 \\
\hline & & & 354 & $\begin{array}{l}\text { Monetary authorities and depository credit } \\
\text { intermediation activities }\end{array}$ & 1.3 \\
\hline & & \multirow{5}{*}{ Bottom 5} & 339 & Couriers and messengers & -1.4 \\
\hline & & & 382 & Employment services & -1.4 \\
\hline & & & 377 & Advertising and related services & -1.5 \\
\hline & & & 340 & Warehousing and storage & -1.9 \\
\hline & & & 360 & Real estate establishments & -6.7 \\
\hline & \multirow{5}{*}{ Induced } & \multirow{5}{*}{ Top 5} & 413 & Food services and drinking places & 8.0 \\
\hline & & & 360 & Real estate establishments & 4.5 \\
\hline & & & 394 & $\begin{array}{l}\text { Offices of physicians, dentists, and other health } \\
\text { practitioners }\end{array}$ & 4.1 \\
\hline & & & 397 & Private hospitals & 3.9 \\
\hline & & & 356 & $\begin{array}{l}\text { Securities, commodity contracts, investments, } \\
\text { and related activities }\end{array}$ & 2.7 \\
\hline \multirow{15}{*}{ High } & \multirow{10}{*}{ Indirect } & \multirow{5}{*}{ Top 5} & 39 & $\begin{array}{l}\text { Maintenance and repair construction } \\
\text { of nonresidential structures }\end{array}$ & 33.2 \\
\hline & & & 369 & Architectural, engineering, and related services & 13.1 \\
\hline & & & 368 & $\begin{array}{l}\text { Accounting, tax preparation, bookkeeping, and } \\
\text { payroll services }\end{array}$ & 12.0 \\
\hline & & & 367 & Legal services & 3.0 \\
\hline & & & 354 & $\begin{array}{l}\text { Monetary authorities and depository credit } \\
\text { intermediation activities }\end{array}$ & 1.8 \\
\hline & & \multirow{5}{*}{ Bottom 5} & 381 & Management of companies and enterprises & -1.9 \\
\hline & & & 377 & Advertising and related services & -2 \\
\hline & & & 382 & Employment services & -2.2 \\
\hline & & & 340 & Warehousing and storage & -2.9 \\
\hline & & & 360 & Real estate establishments & -9.3 \\
\hline & \multirow{5}{*}{ Induced } & \multirow{5}{*}{ Top 5} & 413 & Food services and drinking places & 11.1 \\
\hline & & & 360 & Real estate establishments & 6.2 \\
\hline & & & 394 & $\begin{array}{l}\text { Offices of physicians, dentists, and other health } \\
\text { practitioners }\end{array}$ & 5.6 \\
\hline & & & 397 & Private hospitals & 5.4 \\
\hline & & & 356 & $\begin{array}{l}\text { Securities, commodity contracts, investments, } \\
\text { and related activities }\end{array}$ & 3.5 \\
\hline
\end{tabular}

An examination of the total multiplier for the water and sewer sector indicates that a large (C)Southern Regional Science Association 2019. 
proportion of the estimated impacts are driven by induced/household effects. The indirect effects for each of the multipliers are quite small, as indicated by the Type I multiplier number in the table. Induced effects for output, labor income, and value added account for 30 percent, 27.8 percent, and 25.9 percent, respectively, of the Type II multiplier. The breakdown in Table 6 reflects this multiplier decomposition and also highlights that induced effects account for a greater proportion of total effects than do indirect effects.

\section{DISCUSSION}

While we tend to think of rising water rates and their impact on consumers in isolation, the aggregate choices of consumers could have larger regional economic impacts. To date, however, the regional impacts of rising water prices remain an understudied aspect within the water literature. This gap in our knowledge likely stems from a dearth of publicly available data on water prices, as well as data on water expenditures. Given the data that are available, however, the goal of this study was to outline a scenario-oriented methodology for analyzing water price trends and their potential impact on regional economies. The utility of this multi-regional input-output (MRIO) approach was demonstrated for the three-county region of Maricopa, Pima, and Pinal counties in Arizona. Three water price increase scenarios were created, but expansions to this study with respect to business impacts and different responses in consumer behavior are certainly possible. Here it is important to mention that business impacts, in addition to consumer impacts, are not considered in this study.

Table 6: Multiplier Detail for Select Industries Connected to the Water, Sewage, and Other Treatment and Delivery System Sector in Maricopa County

\begin{tabular}{|c|c|c|c|c|c|}
\hline Type & $\begin{array}{l}\text { Sector } \\
\text { Code }\end{array}$ & Description & $\begin{array}{l}\text { Type I } \\
\text { Multiplier }\end{array}$ & $\begin{array}{l}\text { Induced } \\
\text { Multiplier }\end{array}$ & $\begin{array}{c}\text { Type } \\
\text { SAM/Type } \\
\text { II Multiplier }\end{array}$ \\
\hline \multirow{12}{*}{ Output } & 33 & $\begin{array}{l}\text { Water, sewage \& other treatment } \\
\text { \& delivery systems }\end{array}$ & 1.000 & 0.0008 & 1.008 \\
\hline & 39 & $\begin{array}{l}\text { Maintenance \& repair construction } \\
\text { of nonresidential structures }\end{array}$ & 0.0683 & 0.0027 & 0.0710 \\
\hline & 369 & $\begin{array}{l}\text { Architectural, engineering, \& } \\
\text { related services }\end{array}$ & 0.0220 & 0.0015 & 0.0235 \\
\hline & 368 & $\begin{array}{l}\text { Accounting, tax preparation, } \\
\text { bookkeeping, \& payroll services }\end{array}$ & 0.0174 & 0.0031 & 0.0205 \\
\hline & 354 & $\begin{array}{l}\text { Monetary authorities \& depository } \\
\text { credit intermediation activities }\end{array}$ & 0.0163 & 0.0224 & 0.0387 \\
\hline & 367 & Legal services & 0.0098 & 0.0078 & 0.0175 \\
\hline & 360 & Real estate establishments & 0.0092 & 0.0361 & 0.0454 \\
\hline & 351 & Telecommunications & 0.0080 & 0.0140 & 0.0220 \\
\hline & 356 & $\begin{array}{l}\text { Securities, commodity contracts, } \\
\text { investments, \& related activities }\end{array}$ & 0.0033 & 0.0195 & 0.0228 \\
\hline & 380 & $\begin{array}{l}\text { All other miscellaneous professional, } \\
\text { scientific, \& technical services }\end{array}$ & 0.0032 & 0.0014 & 0.0046 \\
\hline & 355 & $\begin{array}{l}\text { Nondepository credit intermediation } \\
\text { \& related activities }\end{array}$ & 0.0032 & 0.0173 & 0.0204 \\
\hline & \multicolumn{2}{|l|}{ Total } & 1.2129 & 0.5220 & 1.7349 \\
\hline
\end{tabular}

(c)Southern Regional Science Association 2019. 
Table 6: continued from previous page

\begin{tabular}{|c|c|c|c|c|c|}
\hline Type & $\begin{array}{c}\text { Sector } \\
\text { Code }\end{array}$ & Description & $\begin{array}{c}\text { Type I } \\
\text { Multiplier }\end{array}$ & $\begin{array}{l}\text { Induced } \\
\text { Multiplier }\end{array}$ & $\begin{array}{c}\text { Type } \\
\text { SAM/Type } \\
\text { II Multiplier }\end{array}$ \\
\hline \multirow{12}{*}{ Labor Income } & 33 & $\begin{array}{l}\text { Water, sewage \& other treatment } \\
\& \text { delivery systems }\end{array}$ & 1.000 & 0.0008 & 1.008 \\
\hline & 39 & $\begin{array}{l}\text { Maintenance \& repair construction } \\
\text { of nonresidential structures }\end{array}$ & 0.0728 & 0.0029 & 0.0756 \\
\hline & 369 & $\begin{array}{l}\text { Architectural, engineering, \& } \\
\text { related services }\end{array}$ & 0.0354 & 0.0024 & 0.0378 \\
\hline & 368 & $\begin{array}{l}\text { Accounting, tax preparation, } \\
\text { bookkeeping \& payroll services }\end{array}$ & 0.0281 & 0.0049 & 0.0330 \\
\hline & 367 & Legal services & 0.0142 & 0.0113 & 0.0256 \\
\hline & 354 & $\begin{array}{l}\text { Monetary authorities \& depository } \\
\text { credit intermediation activities }\end{array}$ & 0.0067 & 0.0092 & 0.0159 \\
\hline & 355 & $\begin{array}{l}\text { Nondepository credit intermediation } \\
\& \text { related activities }\end{array}$ & 0.0040 & 0.0217 & 0.0257 \\
\hline & 382 & Employment services & 0.0039 & 0.0063 & 0.0102 \\
\hline & 360 & Real estate establishments & 0.0034 & 0.0133 & 0.0166 \\
\hline & 351 & Telecommunications & 0.0034 & 0.0059 & 0.0093 \\
\hline & 374 & $\begin{array}{l}\text { Management, scientific, \& } \\
\text { technical consulting services }\end{array}$ & 0.0032 & 0.0057 & 0.0089 \\
\hline & Total & & 1.2292 & 0.4733 & 1.7025 \\
\hline \multirow{12}{*}{ Value Added } & 33 & $\begin{array}{l}\text { Water, sewage \& other treatment } \\
\& \text { delivery systems }\end{array}$ & 1.000 & 0.0008 & 1.008 \\
\hline & 39 & $\begin{array}{l}\text { Maintenance \& repair construction } \\
\text { of nonresidential structures }\end{array}$ & 0.0469 & 0.0018 & 0.0487 \\
\hline & 368 & $\begin{array}{l}\text { Accounting, tax preparation, } \\
\text { bookkeeping, \& payroll services }\end{array}$ & 0.0175 & 0.0031 & 0.0206 \\
\hline & 369 & $\begin{array}{l}\text { Architectural, engineering, \& } \\
\text { related services }\end{array}$ & 0.0174 & 0.0012 & 0.0185 \\
\hline & 360 & Real estate establishments & 0.0101 & 0.0396 & 0.0497 \\
\hline & 367 & Legal services & 0.0101 & 0.0080 & 0.0181 \\
\hline & 354 & $\begin{array}{l}\text { Monetary authorities \& depository } \\
\text { credit intermediation activities }\end{array}$ & 0.0091 & 0.0124 & 0.0215 \\
\hline & 351 & Telecommunications & 0.0055 & 0.0096 & 0.0151 \\
\hline & 380 & $\begin{array}{l}\text { All other miscellaneous professional, } \\
\text { scientific, \& technical services }\end{array}$ & 0.0033 & 0.0014 & 0.0048 \\
\hline & 366 & Lessors of nonfinancial intangible assets & 0.0030 & 0.0016 & 0.0046 \\
\hline & 319 & Wholesale trade businesses & 0.0026 & 0.0214 & 0.0240 \\
\hline & Total & & 1.1631 & 0.4084 & 1.5714 \\
\hline
\end{tabular}

In addition to possible extensions to this study, it is important to note that these economic impact projections rely on a variety of underlying assumptions. First, the analysis assumes that households do not adopt water efficiency appliances and fixtures or reduce water use in response to increasing prices. While simplistic given the relatively inelastic demand for water (Environmental Protection Agency, 2017), this is not an entirely unrealistic assumption. Further, large aggregate reductions in water use can raise water prices (McGlade, 2015), so the analytical results do not necessarily hinge on this assumption. A second assumption in this paper is that consumers reduce expenditures in consumer goods in amounts that exactly offset the rate increase. This assumption is operationalized by standardizing the regression coefficients by the value of the water price change. Deviations from this offsetting behavior 
could produce smaller or larger impacts than those computed in this study. If consumers reduce spending in the categories indicated by less than the price change, then the economic impacts of this price change will be smaller than those computed in this study. Alternatively, consumers may respond strongly to rate increases and cut spending by more than indicated; in this scenario, the impacts could be greater than projected.

A third assumption is that water price increases will affect every individual household's spending pattern identically. Given prior work which indicates cascading impacts of spending behavior in both the positive and negative directions (Flatters and Willmott, 2009; Frank et al., 2010), this is not entirely unrealistic. Fourth, the use of different input-output models (i.e. RIMS II, REMI, and IMPLAN) can produce variations in results (Rickman and Schwer, 1995). Finally, the results of this study are specific to the three-county region evaluated here. Inter-industry linkages are likely to differ across the country, which will produce variations in results. Based on the methodology outlined however, this approach can be implemented in other regions for which consumer expenditure data and input-output data are available. The estimation of impacts in other regions would be a logical and useful extension to this study.

Aside from impact evaluations in other regions, there are several avenues for future research. One extension would be to obtain survey data from consumers about their spending responses to changes in water prices. These survey data could then be linked to input-output data to provide a direct check of the empirically derived expenditure figures used in this paper. A second extension to this study is an evaluation of business responses to changing water prices. This extension is a bit more challenging given the dearth of information about business uses of water by sector. To overcome this lack of information, simulation analyses could be conducted to estimate all potential changes in spending and obtain a range of regional economic impacts.

\section{CONCLUSION}

While water prices are projected to increase in the U.S. (Walton, 2015, 2017; Mills-Gregg, 2017), there is significant uncertainty as to the amount of these increases. Water rates vary from utility to utility and from customer to customer, which creates additional uncertainty at an individual level. In cases like this, where a variety of unknown and unknowable factors can influence future outcomes, scenario analysis is often used to provide a forecast of a range of possible outcomes (Raskin, 1997). This allows researchers and policymakers to analyze a range of possible outcomes rather than relying on a single prediction that is subject to high uncertainty, particularly as distance from observed data increases. Since rising water rates have implications for household budgets and consumer expenditures, this study used multiregional input-output analysis to examine a range of regional economic impacts using three water price increase scenarios leveraging available data on prices and consumer expenditures on water. Moving forward, methodologies of this nature are important for understanding a range of broader regional impacts associated with consumer behavior related to dynamic water price trends.

(C)Southern Regional Science Association 2019. 


\section{REFERENCES}

American Society for Civil Engineers. (2017a) Drinking Water Infrastructure Report Card. Available online in July 2019 at https://www.infrastructurereportcard.org/wp-content/ uploads/2017/01/Drinking-Water-Final.pdf.

American Society for Civil Engineers. (2017b) Infrastructure Report Card. America's Grades. American Society for Civil Engineers. Available online in July 2019 at https://www. infrastructurereportcard.org/americas-grades/.

American Society for Civil Engineers. (2017c) Wastewater Infrastructure Report Card. Available online in July 2019 at https://www.infrastructurereportcard.org/wp-content/ uploads/2017/01/Wastewater-Final.pdf.

American Water Works Association. (2012) Buried No Longer: Confronting America's Water Infrastructure Challenge. Available online in July 2019 at https://www.awwa.org/Portals/ $0 /$ files/legreg/documents/BuriedNoLonger.pdf.

Baird, Gregory M. (2010) "A Game Plan for Aging Water Infrastructure," American Water Works Association Journal, 102(4), 74-82.

Beecher, Janice A and Peter E Shanaghan. (1998) "Water Affordability and the DWSRF," American Water Works Association Journal, 90(5), 68-75.

Bovarnick, Ben, Shiva Polefka, and Arpita Bhattacharyya. (2014) "Rising Waters, Rising Threat: How Climate Change Endangers America's Neglected Wastewater Infrastructure," Center for American Progress. Available online in July 2019 at https://www.americanprogress.org/issues/green/reports/2014/10/31/100066/ rising-waters-rising-threat/.

Bureau of Labor Statistics. (2018a) Consumer Price Index for All Urban Consumers: All Items, 1997-2017. [Data file]. Available online in July 2019 at https://www.bls.gov/cpi/ data.htm.

Bureau of Labor Statistics. (2018b) Shares of Annual Aggregate Expenditures and Sources of Income: Consumer Expenditure Survey, 2004 - 2016. [Data file]. Available online in July 2019 at https://www.bls.gov/cex/csxcross.htm.

Chapman, Mary M. (2014) "Hundreds in Detroit Protest Over Move to Shut Off Water," New York Times. Available online in July 2019 at https://www.nytimes.com/2014/07/ 19/us/protesters-picket-detroit-over-move-to-shut-off-water.html.

Congressional Budget Office. (2015) Public Spending on Transportation and Water Infrastructure,1956 to 2014. Available online in July 2019 at https://www.cbo.gov/publication/ 49910.

Copeland, Claudia and Mary Tiemann. (2010) Water Infrastructure Needs and Investment: Review and Analysis of Key Issues. Available online in July 2019 at https://fas.org/sgp/ crs/homesec/RL31116.pdf.

Deller, Steven, Ann Hoyt, Brent Hueth, and Reka Sundaram-Stukel. (2009) "Research on the Economic Impact of Cooperatives," University of Wisconsin Center for Cooperatives, 231, 232-233.

Douglas, Aaron J and David A Harpman. (1995) "Estimating Recreation Employment Effects with IMPLAN for the Glen Canyon Dam Region," Journal of Environmental Management, 44(3), 233-247.

Duarte, Rosa, Julio Sanchez-Choliz, and Jorge Bielsa. (2002) "Water Use in the Spanish

(c)Southern Regional Science Association 2019. 
Economy: An Inputoutput Approach," Ecological Economics, 43(1), 71-85.

Environmental Protection Agency. (2016) Expert Workshop on Full Cost Pricing of Water and Wastewater Service, Final Summary Report. Available online in July 2019 at https: //nepis.epa.gov/Exe/ZyPDF.cgi/60000F0Q.PDF?Dockey=60000F0Q.PDF.

Environmental Protection Agency. (2017) Water and Wastewater Pricing. Available online in July 2019 at https://nepis.epa.gov/Exe/ZyPDF.cgi/901U1200.PDF?Dockey=901U1200. PDF.

Environmental Protection Agency. (2018a) How the Drinking Water State Revolving Fund Works. Available online in July 2019 at https://www.epa.gov/drinkingwatersrf/ how-drinking-water-state-revolving-fund-works.

Environmental Protection Agency. (2018b) Learn About the Clean Water State Revolving Fund. Available online in July 2019 at https://www.epa.gov/cwsrf/ learn-about-clean-water-state-revolving-fund-cwsrf.

Environmental Protection Agency. (2018c) Learn About the WIFIA Program. Available online in July 2019 at https://www.epa.gov/wifia/learn-about-wifia-program\#overview.

Faust, Kaseu M, Dulcy M Abraham, and Shawn P McElmurry. (2016) "Water and Wastewater Infrastructure Management in Shrinking Cities," Public Works Management and Policy, 21(2), 128-156.

Fetterman, Mindy. (2016) "As Water Infrastructure Crumbles, Many Cities Seek Private Help," Pew Charitable Trusts. Available online in July 2019 at http://www.pewtrusts.org/en/research-and-analysis/blogs/stateline/2016/03/30/ as-water-infrastructure-crumbles-many-cities-seek-private-help.

Flatters, Paul and Michael Willmott. (2009) "Understanding the Postrecession Consumer," Harvard Business Review, July-August.

Food and Water Watch. (2010) Priceless: The Market Myth of Water Pricing Reform. Available online in July 2019 at https://www.foodandwaterwatch.org/insight/ priceless-market-myth-water-pricing-reform.

Food and Water Watch. (2016) The State of Public Water in the United States. Available online in July 2019 at https://www.foodandwaterwatch.org/sites/default/files/report_state_ of_public_water.pdf.

Forer, Giland and Christine Staub. (2013) "The US water sector on the verge of transformation," Global Cleantech Center White Paper. Available online in July 2019 at http://www.ey.com/Publication/vwLUAssets/Cleantech_Water_Whitepaper/ $\$ FILE/ Cleantech-Water-Whitepaper.pdf.

Frank, Robert H, Adam Seth Levine, and Oege Dijk. (2010) Expenditure Cascades. Available online in July 2019 at https://papers.ssrn.com/sol3/papers.cfm?abstract_id=1690612.

Hunter, George. (2016) "Detroit to Start Water Shut-offs Monday," The Detroit News. Available online in July 2019 at https://www.detroitnews.com/story/news/local/detroit-city/ 2016/04/30/hundreds-detroiters-line-avoid-water-shut-offs/83753926/.

Isard, Walter, Iwan J Azis, Matthew P Drennan, Ronald E Miller, Sidney Saltzman, and Erik Thorbecke. (2017) Methods of Interregional and Regional Analysis. Routledge.

Kamakura, Wagner A and Rex Yuxing Du. (2011) "How Economic Contractions and Expansions Affect Expenditure Patterns," Journal of Consumer Research, 39(2), 229-247.

Kim, Tae. (2018) "Total U.S. Household Debt Soars to Record Above \$13 Trillion," CNBC. Available online in July 2019 at https://www.cnbc.com/2018/02/13/

(C) Southern Regional Science Association 2019. 
total-us-household-debt-soars-to-record-above-13-trillion.html.

Llop, Maria. (2008) "Economic Impact of Alternative Water Policy Scenarios in the Spanish Production System: An Inputoutput Analysis," Ecological Economics, 68(1-2), 288-294.

McGlade, Caitlin. (2015) "Why our Water-saving Ways in Metro Phoenix may not Result in Lower Bills," Arizona Republic. Available online in July 2019 at https://www.azcentral.com/story/news/arizona/investigations/2015/10/29/ so-were-using-less-water-home-now-what/74073662/.

Mills-Gregg, Dorothy. (2017) "City to Notify more than 46,000 Water Customers of Rate Increases," Bakersfield News. Available online in July 2019 at http://www. bakersfield.com/news/city-to-notify-more-than-water-customers-of-rate-increases/ article_b7903e34-6c18-11e7-af0c-7faac7ee7181.html.

Nadolny, Tricia L. (2017) "For Low-income Residents, Philadelphia Unveiling Income-based Water Bills," Philadelphia Inquirer. Available online in July 2019 at http://www.philly.com/philly/news/politics/city/ for-low-income-residents-philadelphia-unveiling-income-based-water-bills-20170620.html.

Nicla, Andrew. (2019) "Does Arizona really Use Less Water Now than it Did in 1957?," Arizona Republic. Available online in July 2019 at https://www.azcentral.com/story/news/local/arizona-environment/2019/02/12/ arizona-water-usage-state-uses-less-now-than-1957/2806899002/.

Pew Research Center. (2010) "A Balance Sheet at 30 Months: How the Great Recession Has Changed Life in America," Pew Research. Available online in July 2019 at https://www.issuelab.org/resource/ a-balance-sheet-at-30-months-how-the-great-recession-has-changed-life-in-america.html. Raskin, Paul. (1997) "Comprehensive Assessment of the Freshwater Resources of the World," Stockholm Environment Institute. Available online in July 2019 at https://www.tellus.org/ pub/Raskin_Comprehensive-Assessment-Freshwater-Resources.pdf.

Rickman, Dan S and R. Keith Schwer. (1995) "A Comparison of the Multipliers of IMPLAN, REMI, and RIMS II: Benchmarking Ready-made Models for Comparison," Annals of Regional Science, 29(4), 363-374.

Terry, Nicquel. (2018) "Group Rallies against Water Shutoffs in Detroit," Detroit News. Available online in July 2019 at https://www.detroitnews.com/story/news/local/ detroit-city/2018/04/23/group-rallies-detroit-water-shutoffs/34172799/.

The Economist. (2011) "Hard Times: How the Economic Slowdown has Changed Consumer Spending in America," The Economist Online. Available online in July 2019 at https: //www.economist.com/graphic-detail/2011/10/25/hard-times.

U.S. Census Bureau. (2018) QuickFacts: Maricopa County, Arizona. Population Estimates. Available online in July 2019 at https://www.census.gov/quickfacts/ maricopacountyarizona.

U.S. Conference of Mayors. (2015) Struggling Local Government Finances and Decelerating Public Water Investment.

U.S. Department of Energy. (2017) Water and Wastewater Annual Price Escalation Rates for Selected Cities across the United States. Available online in July 2019 at https://www. energy.gov/sites/prod/files/2017/10/f38/water_wastewater_escalation_rate_study.pdf.

U.S. Environmental Protection Agency. (2006) Expert Workshop on Full Cost Pricing of Water and Wastewater Service: Final Summary Report. Available online in July 2019 at

(C)Southern Regional Science Association 2019. 
www.epa.gov/safewater.

Walton, Brett. (2015) "Price of Water 2015: Up 6 Percent in 30 Major U.S. Cities; 41 Percent Rise Since 2010," Circle of Blue. Available online in July 2019 at http://www.circleofblue.org/2015/world/ price-of-water-2015-up-6-percent-in-30-major-u-s-cities-41-percent-rise-since-2010/.

Walton, Brett. (2017) "Price of Water 2017: Four Percent Increase in 30 Large U.S. Cities," Circle of Blue. Available online in July 2019 at https://www.circleofblue.org/2017/ water-management/pricing/price-water-2017-four-percent-increase-30-large-u-s-cities/.

Yoo, James, Silvio Simonit, Ann P Kinzig, and Charles Perrings. (2014) "Estimating the Price Elasticity of Residential Water Demand: The Case of Phoenix, Arizona," Applied Economic Perspectives and Policy, 36(2), 333-350.

Zhao, Jing, Hongzhen Ni, Xiujian Peng, Jifeng Li, Genfa Chen, and Jinhua Liu. (2016) "Impact of Water Price Reform on Water Conservation and Economic Growth in China," Economic Analysis and Policy, 51, 90-103.

(c)Southern Regional Science Association 2019. 


\section{APPENDIX}

\begin{tabular}{|c|c|c|c|c|c|c|c|}
\hline & cop & $\begin{array}{c}\text { Primary } \\
\text { County }\end{array}$ & $\begin{array}{l}\text { County } \\
\text {-Level } \\
\text { Impact }\end{array}$ & Emp. & Income & Value Added & Output \\
\hline \multirow{16}{*}{$\begin{array}{l}\text { Direct } \\
\text { Effects }\end{array}$} & \multirow{3}{*}{ Base } & Mar. & $\begin{array}{l}\text { Mar. } \\
\text { Pima } \\
\text { Pinal }\end{array}$ & -113.0 & $\$ 4,226,932$ & $\$ 12,342,724$ & $\$ 10,601,434$ \\
\hline & & Pima & $\begin{array}{l}\text { Pima } \\
\text { Mar. } \\
\text { Pinal }\end{array}$ & -28.6 & $\$ 516,629$ & $\$ 3,174,381$ & $\$ 2,863,307$ \\
\hline & & Pinal & $\begin{array}{l}\text { Pinal } \\
\text { Mar. } \\
\text { Pinal }\end{array}$ & -9.0 & $\$ 162,089$ & $\$ 995,939$ & $\$ 898,342$ \\
\hline & Total & & & -150.6 & $\$ 4,905,650$ & $\$ 16,513,044$ & $\$ 14,363,083$ \\
\hline & \multirow{3}{*}{ Mid. } & Mar. & $\begin{array}{l}\text { Mar. } \\
\text { Pima } \\
\text { Pinal }\end{array}$ & -182.3 & $\$ 6,849,657$ & $\$ 20,001,129$ & $\$ 17,179,405$ \\
\hline & & Pima & $\begin{array}{l}\text { Pima } \\
\text { Mar. } \\
\text { Pinal }\end{array}$ & -46.3 & $\$ 837,187$ & $\$ 5,144,018$ & $\$ 4,639,931$ \\
\hline & & Pinal & $\begin{array}{l}\text { Pinal } \\
\text { Mar. } \\
\text { Pinal }\end{array}$ & -14.5 & $\$ 262,661$ & $\$ 1,613,899$ & $\$ 1,455,745$ \\
\hline & Total & & & -243.1 & $\$ 7,949,505$ & $\$ 26,759,046$ & $\$ 23,275,081$ \\
\hline & \multirow{3}{*}{ High } & Mar. & $\begin{array}{l}\text { Mar. } \\
\text { Pima } \\
\text { Pinal }\end{array}$ & -273.4 & $\$ 10,274,485$ & $\$ 30,001,694$ & $\$ 25,769,108$ \\
\hline & & Pima & $\begin{array}{l}\text { Pima } \\
\text { Mar. } \\
\text { Pinal }\end{array}$ & -69.5 & $\$ 1,255,780$ & $\$ 7,716,027$ & $\$ 6,959,896$ \\
\hline & & Pinal & $\begin{array}{l}\text { Pinal } \\
\text { Mar. } \\
\text { Pinal }\end{array}$ & -18.3 & $\$ 250,037$ & $\$ 2,328,043$ & $\$ 2,183,618$ \\
\hline & Total & & & -361.2 & $\$ 11,780,302$ & $\$ 40,045,764$ & $\$ 34,912,622$ \\
\hline & \multirow{3}{*}{ Base } & Mar. & $\begin{array}{l}\text { Mar. } \\
\text { Pima } \\
\text { Pinal }\end{array}$ & $\begin{array}{r}6.9 \\
0.0 \\
-0.1 \\
\end{array}$ & $\begin{array}{c}\$ 738,667 \\
\$ 4,533 \\
-\$ 3,736\end{array}$ & $\begin{array}{c}\$ 489,182 \\
\$ 2,981 \\
-\$ 8,787\end{array}$ & $\begin{array}{c}\$ 1,430,412 \\
\$ 16,793 \\
-\$ 23,007\end{array}$ \\
\hline & & Pima & $\begin{array}{l}\text { Pima } \\
\text { Mar. } \\
\text { Pinal }\end{array}$ & $\begin{array}{c}3.4 \\
-0.3 \\
0.00\end{array}$ & $\begin{array}{c}\$ 229,901 \\
-\$ 17,123 \\
-\$ 833\end{array}$ & $\begin{array}{c}\$ 209,187 \\
-\$ 34,069 \\
-\$ 1,857\end{array}$ & $\begin{array}{c}\$ 553,554 \\
-\$ 56,831 \\
-\$ 5,568\end{array}$ \\
\hline & & Pinal & $\begin{array}{l}\text { Pinal } \\
\text { Mar. } \\
\text { Pinal }\end{array}$ & $\begin{array}{l}1.6 \\
0.0 \\
1.6\end{array}$ & $\begin{array}{c}\$ 97,742 \\
\$ 498 \\
\$ 98,065\end{array}$ & $\begin{array}{c}\$ 105,332 \\
-\$ 1,395 \\
\$ 105,575\end{array}$ & $\begin{array}{c}\$ 242,285 \\
-\$ 2,654 \\
\$ 242,958\end{array}$ \\
\hline & Total & & & 13.1 & $\$ 1,147,714$ & $\$ 866,149$ & $\$ 2,397,942$ \\
\hline
\end{tabular}

(C)Southern Regional Science Association 2019. 


\begin{tabular}{|c|c|c|c|c|c|c|c|}
\hline \multirow{18}{*}{$\begin{array}{l}\text { Indirect } \\
\text { Effects }\end{array}$} & \multirow{7}{*}{ Mid. } & Mar. & $\begin{array}{l}\text { Mar. } \\
\text { Pima } \\
\text { Pinal }\end{array}$ & $\begin{array}{c}11.1 \\
0.0 \\
-0.1\end{array}$ & $\begin{array}{c}\$ 1,196,995 \\
\$ 7,345 \\
-\$ 6,054\end{array}$ & $\begin{array}{c}\$ 792,709 \\
\$ 4,830 \\
-\$ 14,239\end{array}$ & $\begin{array}{c}\$ 2,317,953 \\
\$ 27,213 \\
-\$ 37,282\end{array}$ \\
\hline & & \multirow{3}{*}{ Pima } & Pima & 5.5 & $\$ 372,551$ & $\$ 338,984$ & $\$ 897,023$ \\
\hline & & & Mar. & -0.5 & $-\$ 27,748$ & $-\$ 55,208$ & $-\$ 92,093$ \\
\hline & & & Pinal & 0.0 & $-\$ 1,349$ & $-\$ 3,009$ & $-\$ 9,002$ \\
\hline & & \multirow{3}{*}{ Pinal } & Pinal & 2.7 & $\$ 158,388$ & $\$ 170,688$ & $\$ 392,618$ \\
\hline & & & Mar. & 0.0 & $\$ 808$ & $-\$ 2,260$ & $-\$ 4,300$ \\
\hline & & & Pinal & 2.7 & $\$ 158,913$ & $\$ 171,082$ & $\$ 393,709$ \\
\hline & Total & & & 21.4 & $\$ 1,859,849$ & $\$ 1,403,577$ & $\$ 3,885,819$ \\
\hline & \multirow{9}{*}{ High } & \multirow{3}{*}{ Mar. } & Mar. & 16.7 & $\$ 1,795,492$ & $\$ 1,189,063$ & $\$ 3,476,930$ \\
\hline & & & Pima & 0.0 & $\$ 11,018$ & $\$ 7,245$ & $\$ 40,819$ \\
\hline & & & Pinal & -0.1 & $-\$ 9,081$ & $-\$ 21,358$ & $-\$ 55,923$ \\
\hline & & \multirow{3}{*}{ Pima } & Pima & 8.2 & $\$ 558,826$ & $\$ 508,476$ & $\$ 1,345,534$ \\
\hline & & & Mar. & -0.7 & $-\$ 41,622$ & $-\$ 82,813$ & $-\$ 138,140$ \\
\hline & & & Pinal & 0.0 & $-\$ 2,024$ & $-\$ 4,514$ & $-\$ 13,533$ \\
\hline & & \multirow{3}{*}{ Pinal } & Pinal & 0.9 & $\$ 37,150$ & $\$ 23,371$ & $\$ 111,191$ \\
\hline & & & Mar. & -0.5 & $-\$ 17,869$ & $-\$ 69,718$ & $-\$ 93,226$ \\
\hline & & & Pinal & -0.1 & $-\$ 387$ & $-\$ 3,087$ & $\$ 13$ \\
\hline & \multicolumn{2}{|l|}{ Total } & & 24.4 & $\$ 2,331,503$ & $\$ 1,546,665$ & $\$ 4,673,665$ \\
\hline \multirow{24}{*}{$\begin{array}{l}\text { Induced } \\
\text { Effects }\end{array}$} & \multirow{9}{*}{ Base } & \multirow{3}{*}{ Mar. } & Mar. & 38.3 & $\$ 1,909,157$ & $\$ 3,410,008$ & $\$ 5,263,194$ \\
\hline & & & Pima & 0.1 & $\$ 5,929$ & $\$ 11,131$ & $\$ 20,925$ \\
\hline & & & Pinal & 0.0 & $\$ 2,030$ & $\$ 3,855$ & $\$ 9,641$ \\
\hline & & \multirow{3}{*}{ Pima } & Pima & 5.0 & $\$ 193,737$ & $\$ 367,913$ & $\$ 589,132$ \\
\hline & & & Mar. & 0.1 & $\$ 5,366$ & $\$ 7,866$ & $\$ 13,339$ \\
\hline & & & Pinal & 0.0 & $\$ 197$ & $\$ 363$ & $\$ 820$ \\
\hline & & \multirow{3}{*}{ Pinal } & Pinal & 2.4 & $\$ 93,706$ & $\$ 175,340$ & $\$ 287,343$ \\
\hline & & & Mar. & 0.2 & $\$ 10,111$ & $\$ 16,578$ & $\$ 26,627$ \\
\hline & & & Pinal & 1.6 & $\$ 62,705$ & $\$ 116,610$ & $\$ 195,009$ \\
\hline & Total & & & 47.7 & $\$ 2,282,938$ & $\$ 4,109,664$ & $\$ 6,406,030$ \\
\hline & \multirow{9}{*}{ Mid. } & \multirow{3}{*}{ Mar. } & Mar. & 62.1 & $\$ 3,093,750$ & $\$ 5,525,848$ & $\$ 8,528,898$ \\
\hline & & & Pima & 0.2 & $\$ 9,607$ & $\$ 18,037$ & $\$ 33,908$ \\
\hline & & & Pinal & 0.1 & $\$ 3,290$ & $\$ 6,247$ & $\$ 15,623$ \\
\hline & & \multirow{3}{*}{ Pima } & Pima & 8.1 & $\$ 313,947$ & $\$ 596,195$ & $\$ 954,676$ \\
\hline & & & Mar. & 0.1 & $\$ 8,695$ & $\$ 12,747$ & $\$ 21,616$ \\
\hline & & & Pinal & 0.0 & $\$ 319$ & $\$ 589$ & $\$ 1,329$ \\
\hline & & \multirow{3}{*}{ Pinal } & Pinal & 3.9 & $\$ 151,849$ & $\$ 284,136$ & $\$ 465,636$ \\
\hline & & & Mar. & 0.3 & $\$ 16,384$ & $\$ 26,864$ & $\$ 43,149$ \\
\hline & & & Pinal & 2.6 & $\$ 101,612$ & $\$ 188,964$ & $\$ 316,008$ \\
\hline & \multirow[t]{5}{*}{ Total } & \multirow{5}{*}{ Mar. } & & 77.4 & $\$ 3,699,453$ & $\$ 6,659,627$ & $\$ 10,380,843$ \\
\hline & & & Mar. & 93.2 & $\$ 4,640,625$ & $\$ 8,288,771$ & $\$ 12,793,346$ \\
\hline & & & Pima & 0.3 & $\$ 14,411$ & $\$ 27,056$ & $\$ 50,862$ \\
\hline & & & Pinal & 0.1 & $\$ 4,935$ & $\$ 9,370$ & $\$ 23,435$ \\
\hline & & & Pima & 12.1 & $\$ 470,920$ & $\$ 894,292$ & $\$ 1,432,014$ \\
\hline
\end{tabular}

High Pima

(c)Southern Regional Science Association 2019. 


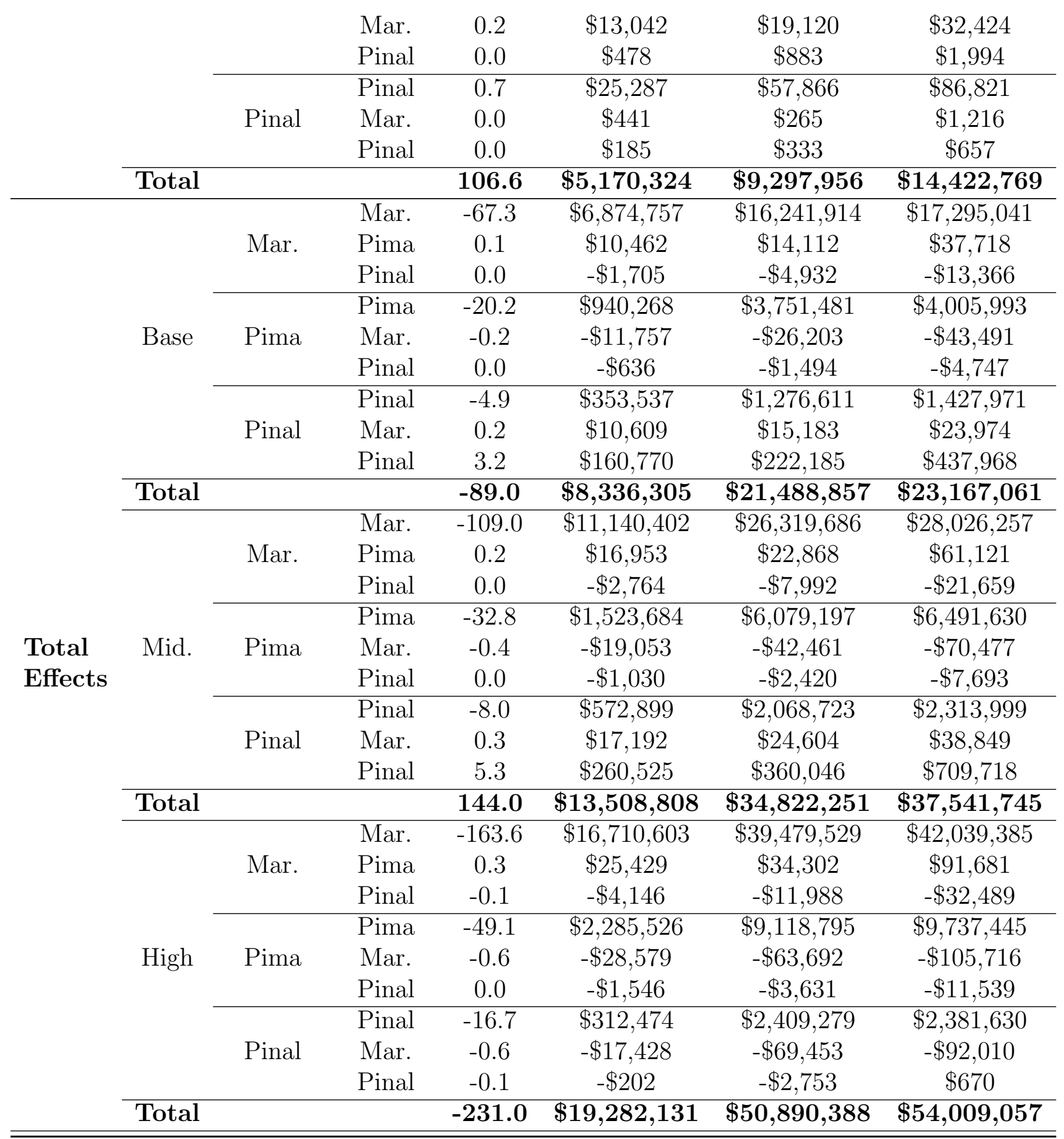

(C)Southern Regional Science Association 2019. 